\title{
Fluid Biomarkers in Alzheimer Disease
}

\author{
Kaj Blennow ${ }^{1}$, Henrik Zetterberg ${ }^{1}$, and Anne M. Fagan ${ }^{2}$ \\ ${ }^{1}$ Clinical Neurochemistry Laboratory, Institute of Neuroscience and Physiology, Department of Psychiatry \\ and Neurochemistry, The Sahlgrenska Academy at University of Gothenburg, Sahlgrenska University \\ Hospital, Mölndal, SE-431 80 Mölndal, Sweden \\ ${ }^{2}$ Department of Neurology, The Charles F. and Joanne Knight Alzheimer's Disease Research Center, \\ Hope Center for Neurological Disorders, Washington University School of Medicine, St. Louis, \\ Missouri 63110 \\ Correspondence: kaj.blennow@neuro.gu.se
}

Research progress has provided detailed understanding of the molecular pathogenesis of Alzheimer disease (AD). This knowledge has been translated into new drug candidates with putative disease-modifying effects, which are now being tested in clinical trials. The promise of effective therapy has created a great need for biomarkers able to detect AD in the predementia phase, because drugs will probably be effective only if neurodegeneration is not too advanced. In this chapter, cerebrospinal fluid (CSF) and plasma biomarkers are reviewed. The core CSF biomarkers total tau (T-tau), phosphorylated tau (P-tau) and the 42 amino acid form of $\beta$-amyloid (A $\beta 42$ ) reflect $A D$ pathology, and have high diagnostic accuracy to diagnose $\mathrm{AD}$ with dementia and prodromal $\mathrm{AD}$ in mild cognitive impairment cases. The rationale for the use of CSF biomarkers to identify and monitor the mechanism of action of new drug candidates is also outlined in this chapter.

In 1906, Alois Alzheimer presented the first case of the disease that was to bear his name, Alzheimer disease (AD). Alzheimer described the "miliary bodies" ( plaques) and "dense bundles of fibrils" (tangles) which we today know are the hallmarks of the disease. In 1985, researchers succeeded in purifying plaque cores and amyloid angiopathy, and the $4 \mathrm{kD} \beta$-amyloid $(A \beta)$ peptide was identified as the main component (Glenner and Wong 1984; Masters et al. 1985). This breakthrough paved the way for the cloning of the amyloid precursor protein (APP) gene (Kang et al. 1987). Almost at the same time, it was shown that tangles are composed of abnormally hyperphosphorylated tau protein (Grundke-Iqbal et al. 1986). These important achievements marked the start of modern AD research.

Today, detailed knowledge is available about APP metabolism and $A \beta$ generation and on tau protein homeostasis. Largely based on the mutations found in familial $\mathrm{AD}$ (FAD), $\mathrm{A} \beta$ has been proposed as the driving force in the disease process. In line with this, the "amyloid cascade hypothesis" for AD (Hardy and Selkoe 2002) posits that an imbalance between the production and clearance of $A \beta$ is the initiating event in disease pathogenesis, ultimately leading to neuronal degeneration and dementia. This research progress has been translated into

Editors: Dennis J. Selkoe, Eckhard Mandelkow, and David M. Holtzman

Additional Perspectives on The Biology of Alzheimer Disease available at www.perspectivesinmedicine.org

Copyright (C) 2012 Cold Spring Harbor Laboratory Press; all rights reserved; doi: 10.1101/cshperspect.a006221

Cite this article as Cold Spring Harb Perspect Med 2012;2:a006221 
K. Blennow et al.

novel treatment strategies with disease-modifying potential. A large number of anti-A $\beta$ drug candidates, such as those used in $\mathrm{A} \beta$ immunotherapy, secretase inhibitors, and $\mathrm{A} \beta$ aggregation inhibitors, are in various phases of clinical treatment trials (Blennow et al. 2006). It should be noted, however, that the amyloid cascade hypothesis has not been proven with certainty in late-onset $\mathrm{AD}$, the most common form of the disease.

Disease-modifying drugs will probably be most effective in the earlier stages of the disease, before plaque and tangle load and neurodegeneration become too severe (Das et al. 2001; Levites et al. 2006; Garcia-Alloza et al. 2009). Thus, these treatments should be administered in the predementia stage, or even in presymptomatic individuals. Further, in order for treatments to be labeled as "disease-modifying," they must show a beneficial effect on cognition, as well as evidence that the drug does indeed affect the central disease processes and hallmark neuropathology (Siemers 2009). These challenges have created a need for biomarkers that reflect core elements of the disease process, to serve as diagnostic aids and as tools to identify and monitor the biochemical mechanism of action of the drug. In this chapter, we review the development of candidate biomarkers of $\mathrm{AD}$ from cerebrospinal fluid (CSF) and plasma. We focus on established biomarkers, those that have been evaluated in several studies by different research groups, and we discuss their implementation in clinical routine and their potential role in clinical trials.

\section{FLUID BIOMARKERS AND THE BRAIN}

Biomarkers are objective measures of a biological or pathogenic process that can be used to evaluate disease risk or prognosis, to guide clinical diagnosis, or to monitor therapeutic interventions (Blennow et al. 2010). The CSF is in direct contact with the extracellular space of the brain, and biochemical changes in the brain are therefore reflected in the CSF. The CSF is thus the optimal source for $\mathrm{AD}$ biomarkers.

Since $A \beta 42$ and tau have been shown to be the primary protein components of amyloid plaques and neurofibrillary tangles, respectively, the levels of these proteins in CSF have been assessed as potential biomarkers of these pathologic features (Fig. 1). Levels of $A \beta 42$ in postmortem ventricular CSF have been shown to correlate with plaque load at autopsy (Strozyk et al. 2003). Similar results have been reported in antemortem lumbar CSF, with low levels correlating with postmortem plaque load (Tapiola et al. 2009). The development of $A \beta$ ligands suitable for positron emission tomography (PET) has enabled direct visualization of fibrillar $A \beta$ load in the brain in living individuals. Studies have consistently found a relationship between in vivo amyloid load as assessed by Pittsburgh Compound B (PIB)-PET binding and CSF $A \beta 42$, with higher ${ }^{11 C} \mathrm{PIB}$ binding correlating with lower CSF A $\beta 42$ levels (Fagan et al. 2006; Forsberg et al. 2008; Grimmer et al. 2009; Tolboom et al. 2009). A similar relationship has been found between CSF $\mathrm{A} \beta 42$ and binding of ${ }^{18 \mathrm{~F}}$ FDDNP, a PET ligand believed to label both plaques and tangles (Tolboom et al. 2009). These results support the idea that CSF $A \beta 42$ is a measure of fibrillar A $\beta 42$ and plaque load in the brain. The most widely accepted explanation for the reduced CSF level of $A \beta 42$ in $A D$ is that the aggregation of $A \beta$ into plaques (and thus retention in the brain parenchyma) results in less $A \beta$ being available to diffuse into the CSF.

Evidence that CSF total tau (T-tau) reflects the intensity of the neuronal and axonal damage and degeneration has come from several types of studies (Fig. 1). CSF T-tau increases markedly and transiently in acute disorders such as stroke and brain trauma, and the magnitude of the increase positively correlates with the size of the damaged tissue and negatively correlates with clinical outcome (Hesse et al. 2001; Ost et al. 2006; Zetterberg et al. 2006). The degree of increase in CSF T-tau in chronic neurodegenerative disorders is highest in disorders with the most rapid neuronal degeneration, such as Creutzfeldt-Jakob disease (Otto et al. 1997). High CSF T-tau is also associated with a faster progression from mild cognitive impairment (MCI) to AD (Blom et al. 2009), and a more rapid cognitive decline and higher mortality in 
Fluid Biomarkers in Alzheimer Disease

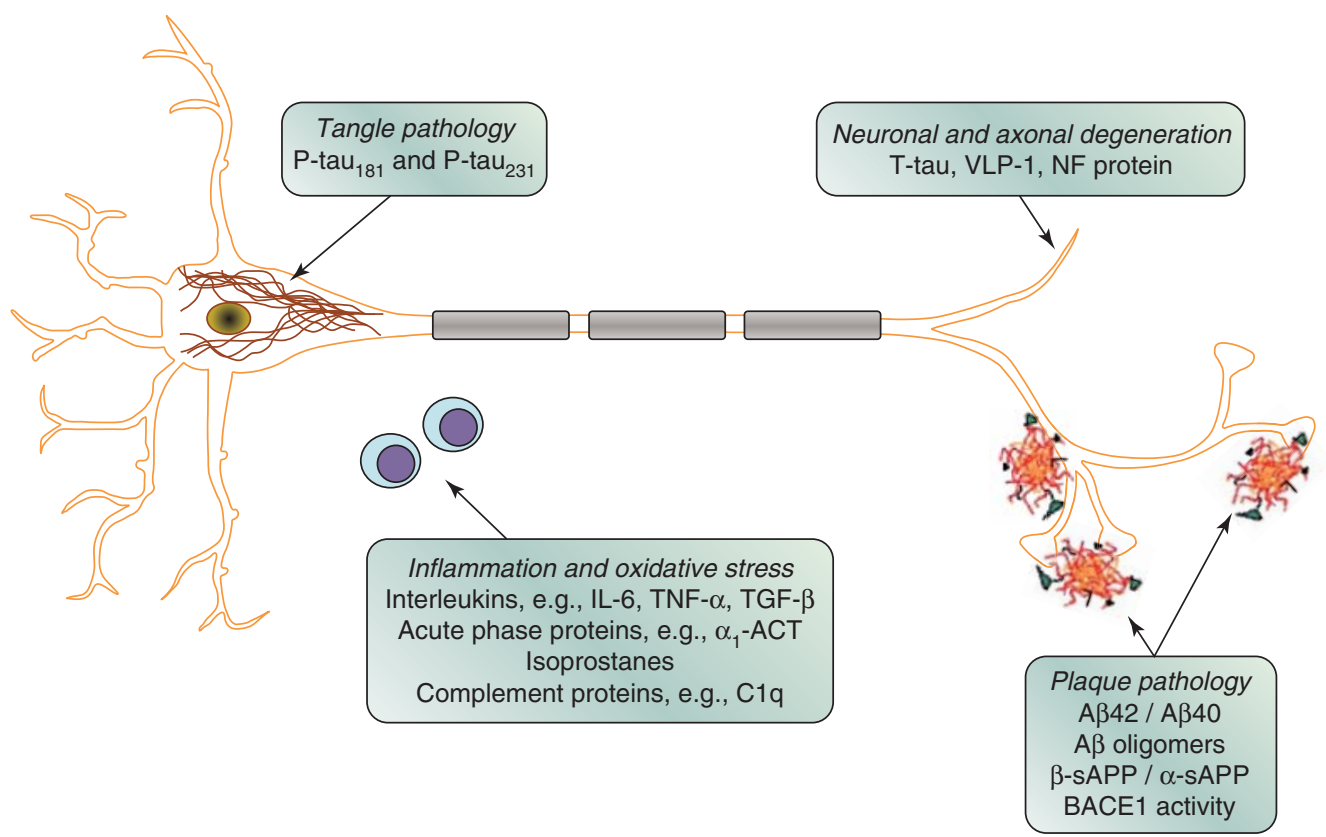

Figure 1. Schematic drawing of a neuron with intracellular neurofibrillary tangles and three neuritic plaques, together with two lymphocytes. Candidate cerebrospinal fluid biomarkers for different pathogenic processes are given.

AD cases (Samgard et al. 2009; Wallin et al. 2009). However, one study found that CSF Ttau correlates with postmortem tangle load (Tapiola et al. 2009), suggesting that the release of tau specifically from degenerating tanglebearing neurons may contribute to the CSF level of T-tau. Consistent with this idea, binding of ${ }^{18 \mathrm{~F}}$ FDDNP, an agent that is reported to label both plaques and tangles, positively correlates with CSF T-tau levels (Tolboom et al. 2009).

It is logical to postulate that phosphorylated tau (P-tau) in CSF reflects the phosphorylation state of the tau protein in the central nervous system (CNS; Fig. 1). Positive correlations between CSF levels of P-tau ${ }_{181}$ and P-tau 231 (tau phosphorylated at residues 181 and 231, respectively) and neocortical tangle pathology at autopsy have been reported (Buerger et al. 2006; Tapiola et al. 2009). High CSF P-tau181 is also associated with a faster progression from MCI to AD (Blom et al. 2009), and a more rapid cognitive decline in $\mathrm{AD}$ cases
(Samgard et al. 2009), as well as those with very mild AD dementia (Snider et al. 2009). These findings support the hypothesis that the CSF level of P-tau reflects the phosphorylation state of tau and the formation of tangles in the brain.

\section{FLUID BIOMARKERS FOR AD DIAGNOSIS}

\section{$\beta$-Amyloid Isoforms}

The discovery that $\beta$-amyloid $(A \beta)$ is produced during normal cell metabolism and is secreted into the CSF served as the basis for $A \beta$ biomarker development (Seubert et al. 1992). The subsequent finding that $A \beta 42$ is the most abundant species in plaques made it logical to develop assays for this $A \beta$ isoform (Jarrett et al. 1993). CSF $\mathrm{A} \beta 42$ in $\mathrm{AD}$ is decreased to approximately $50 \%$ of control levels, as has been shown using several different enzymelinked immunosorbent assay (ELISA) methods (Sunderland et al. 2003; Blennow 2004). 
K. Blennow et al.

\section{Tau Protein}

There are several isoforms of the tau protein in CSF, and the molecule has numerous phosphorylation sites (Portelius et al. 2008). The most commonly used ELISA method for T-tau is based on monoclonal antibodies that detect all isoforms of tau independently of phosphorylation state (Blennow et al. 1995). Numerous studies have used this assay, and consistently report a marked increase of CSF T-tau in AD to around $300 \%$ of control levels (Sunderland et al. 2003; Blennow 2004).

\section{Phosphorylated Tau Protein}

The most commonly used ELISA methods for P-tau in CSF use antibodies that are specific for phosphorylation at either threonine 181 (P-Tau181) or threonine 231 (P-Tau231; Kohnken et al. 2000; Vanmechelen et al. 2000). Studies using these assays have consistently found a marked increase in CSF P-tau in AD (Blennow 2004). Research that compared these P-tau assays directly found a very high correlation between the methods and similar diagnostic performances (Hampel et al. 2004).

\section{Combination of Tau and $\mathrm{A} \beta$ as Biomarkers}

Several studies have shown that the diagnostic accuracy for the combination of CSF T-tau, P-tau and $A \beta 42$ is higher than for any biomarker alone (Galasko et al. 1998; Reimenschneider et al. 2002; Maddalena et al. 2003; Zetterberg et al. 2003; Hansson et al. 2006). A logical strategy, therefore, was to develop a multiparameter assay for simultaneous quantification of these CSF biomarkers, based on the Luminex $^{\mathrm{TM}}$ xMAP technology (Olsson et al. 2005). This assay has been used in several recent large multicenter studies on CSF biomarkers, and its diagnostic performance has been good (Hansson et al. 2006; Lewczuk et al. 2008; Mattsson et al. 2009; Shaw et al. 2009). The measured values for CSF levels of the biomarkers differ between the Luminex technique and the ELISA methods (Olsson et al. 2005; Lewczuk et al. 2008). There are likely to be several reasons for this, including differences in the pairs of antibodies selected, the method for coupling antibodies to beads, the method of coating plates, differences in the calibrators, and differences in the incubation conditions. Correction factors have been used to convert results from one technique to the other, allowing the results to be compared (Olsson et al. 2005; Mattsson et al. 2009).

\section{DIAGNOSTIC PERFORMANCE OF FLUID BIOMARKERS}

\section{AD with Dementia}

Numerous studies have found a marked increase in CSF T-tau and P-tau, together with a marked decrease in $\mathrm{A} \beta 42$, in $\mathrm{AD}$ cases with dementia. These measurements can be used to discriminate patients with $\mathrm{AD}$ from the nondemented aged with a sensitivity and specificity that both lie above $80 \%$ (Blennow and Hampel 2003; Blennow 2004). CSF levels of these markers are normal in several important differential diagnoses, such as depression and Parkinson disease (Blennow 2004). Combined analyses of these biomarkers give a better diagnostic performance than any biomarker alone (Galasko et al. 1998; Maddalena et al. 2003; Hansson et al. 2006; Mattsson et al. 2009). CSF P-tau, in particular, aids in the differentiation of $\mathrm{AD}$ from other dementias, such as frontotemporal dementia and Lewy body dementia (Hampel et al. 2004), but the diagnostic performance of CSF biomarkers to discriminate $\mathrm{AD}$ from other dementias is not optimal. There are several reasons for this. First, most studies of CSF biomarkers are based on clinically diagnosed cases, which introduces a relatively large percentage of misdiagnosis (Blennow 2005; Forman et al. 2006). Second, a significant percentage of the nondemented elderly have enough plaques and tangles to warrant a neuropathological diagnosis of AD (Snowdon 1997; Price and Morris 1999). Third, there is a large overlap in pathology between $\mathrm{AD}$ and other dementias, such as Lewy body dementia and vascular dementia (Jellinger 1996; Kotzbauer et al. 2001; Schneider et al. 2009). This overlap in pathology essentially precludes the possibility 
of finding any biomarkers that have close to $100 \%$ sensitivity and specificity for AD.

\section{Autopsy-Verified AD}

Several studies have examined the diagnostic performance of CSF biomarkers in patient series in which diagnosis can subsequently be confirmed by autopsy. CSF biomarkers have high sensitivity and specificity in discriminating $\mathrm{AD}$ from both the cognitively normal elderly and from patients with other dementias, such as frontotemporal dementia, Lewy body dementia and vascular dementia (Clark et al. 2003; Sunderland et al. 2003; Bian et al. 2008; Koopman et al. 2009; Shaw et al. 2009). CSF biomarkers have thus been validated in patient series with a neuropathological follow-up, showing similar or better discriminatory power than in patient series with clinical diagnoses only.

\section{Prodromal AD}

Cerebrospinal fluid biomarkers also have a high predictive value in identifying prodromal AD in MCI cases (Blennow and Hampel 2003). A recent study with an extended clinical followup period showed that the combination of all three core CSF biomarkers (T-tau, P-tau, and A 342 ) had a sensitivity of $95 \%$ for the identification of prodromal AD in MCI (Hansson et al. 2006). These CSF markers have also been shown to predict the rate of cognitive decline in patients with $\mathrm{MCI}$ /very mild $\mathrm{AD}$ dementia (Snider et al. 2009). A high predictive value has also been verified in large multicenter studies, including the ADNI study (Shaw et al. 2009), the DESCRIPA study (Visser et al. 2009), and the Swedish Brain Power project (Mattsson et al. 2009). These results demonstrate that CSF biomarkers may be valuable clinical diagnostic tools to identify MCI cases with prodromal AD.

\section{Preclinical AD}

Preclinical AD denotes cognitively normal individuals harboring early $\mathrm{AD}$ pathology, not severe enough to cause cognitive symptoms.
Some studies have examined whether CSF biomarkers are useful in the preclinical stage to identify patients who will subsequently develop $\mathrm{AD}$ dementia. Two population-based studies found a significant reduction in CSF A $\beta 42$ in cognitively normal elderly who later developed $\mathrm{AD}$, whereas there was no significant change in CSF T-tau or P-tau (Skoog et al. 2003; Gustafson et al. 2007). A recent clinical study also found that CSF $A \beta 42$, but not T-tau and P-tau, predicts cognitive decline in the healthy elderly (Stomrud et al. 2007). Four independent studies have identified the CSF tau/A $\beta 42$ ratio (but not these markers individually) as a strong predictor of future cognitive decline (within a few years) in nondemented elders (Fagan et al. 2007; Li et al. 2007; Craig-Schapiro et al. 2010; Tarawneh et al. 2011), similar to its ability to predict AD dementia in MCI cohorts (Hansson et al. 2006). Asymptomatic carriers of FAD mutations also have low CSF A $\beta 42$ (Moonis et al. 2005), and high T-tau and P-tau (Ringman et al. 2008). These results extend earlier animal data suggesting that the amyloidogenic process is upstream of tau pathology in $\mathrm{AD}$ (Gotz et al. 2001; Lewis et al. 2001). Consistent with this idea, two recent studies reported an association between low CSF A $\beta 42$ levels and brain atrophy in cognitively normal elders (Fagan et al. 2009a; Fjell et al. 2010), whereas CSF tau and ptau181 levels were associated with atrophy in earlystage MCI/AD (Fagan et al. 2009a). These biomarker observations suggest that $A \beta$ aggregation and deposition (as evidenced by reduced CSF A 342 ) are associated with brain atrophy in the preclinical phase of the disease, whereas changes in CSF tau and accelerated brain atrophy are later events in the disease that occur with or just prior to cognitive decline and subsequent clinical progression (Fig. 2). Additional studies are required to confirm these findings.

A recent large study showed that cognitively normal elderly who are positive for PIB-PET (indicating the presence of brain amyloid) have low levels of CSF A $\beta 42$ (Fagan et al. 2009b), confirming results from an earlier, smaller study (Fagan et al. 2006). However, in this larger cohort, CSF A $\beta 42$ was found to also be low in a small subset of PIB-negative 
K. Blennow et al.
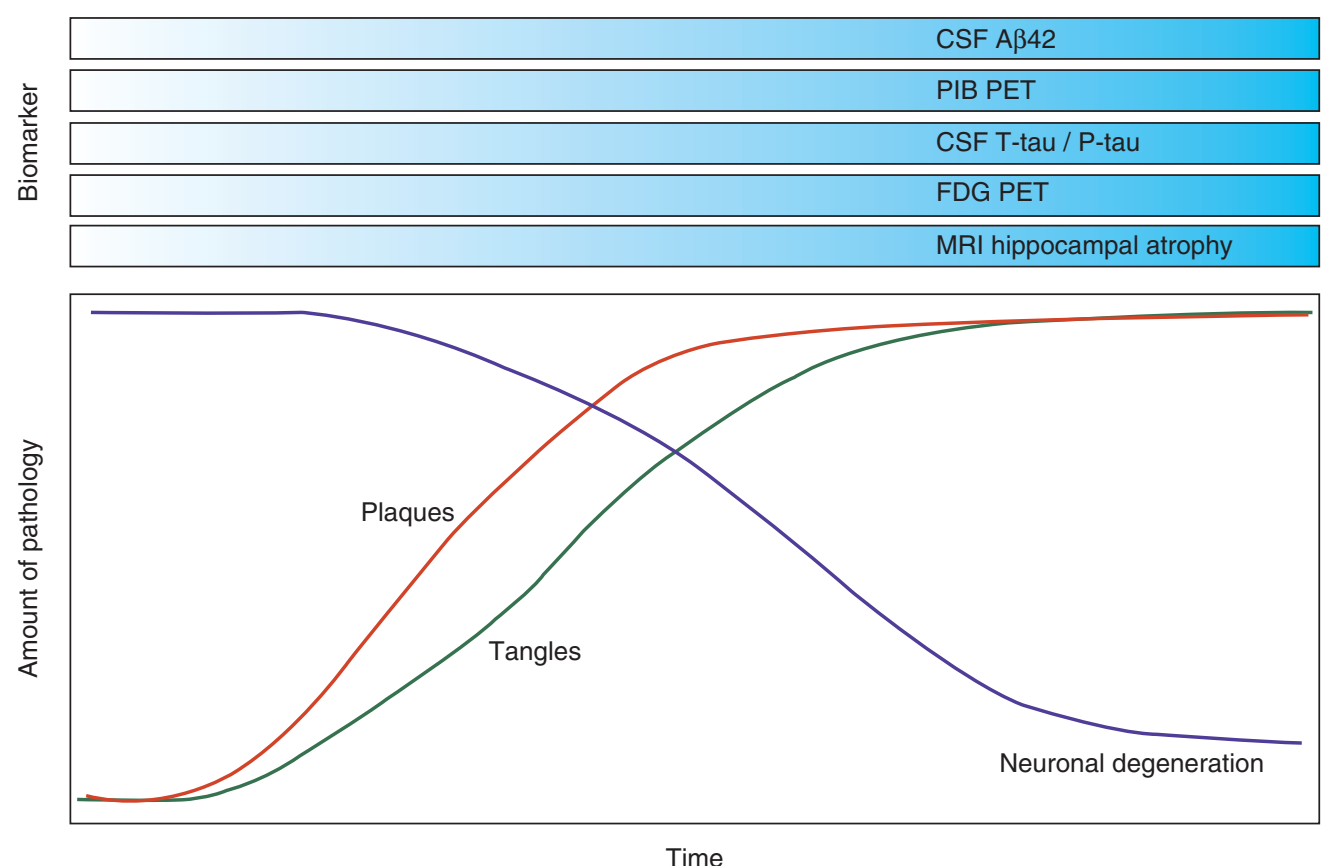

\begin{tabular}{|cccccc|}
\hline No AD & Preclinical AD & Prodromal AD $(\mathrm{MCl})$ & Mild AD & Moderate AD & Severe AD \\
CDR 0 & CDR 0 & CDR 0.5 & CDR 1 & CDR 2 & CDR 3 \\
\hline
\end{tabular}

Stage of disease

Figure 2. Hypothetical model of the temporal evolution of biomarkers for Alzheimer disease (AD) (top) in relation to pathogenic processes in the brain (middle) and clinical stage of the disease (bottom).

individuals (Fagan et al. 2009b). This finding suggests that low CSF A $\beta 42$ may serve as a harbinger of future amyloid deposition in the preclinical period. Longitudinal PIB follow-up in these individuals will be required to test this hypothesis. Alternatively, low CSF A $\beta 42$ in the absence of PIB positivity may be an indicator of $A \beta$ aggregation in diffuse (PIB-negative) plaques or the accumulation of oligomeric species of $A \beta$ within brain parenchyma prior to substantial fibrillar (PIB-positive) A $\beta$ deposition, or may simply reflect the low end of the normal spectrum of CSF $A \beta 42$ levels. In support of the first alternative hypothesis, one of the PIB-negative individuals with low CSF A $\beta 42$ came to autopsy and was found to have widespread diffuse, but minimal fibrillar, plaque deposits, suggesting that low CSF A 342 may mark diffuse plaques in addition to fibrillar plaques (Cairns et al. 2009). Regardless of the underlying biological mechanism(s), these results suggest that CSF $A \beta 42$ is a marker of $\mathrm{AD}$ plaque pathology very early in the disease process (prior to cognitive symptoms). However, it remains to be determined whether CSF $\mathrm{A} \beta 42$ levels will allow the prediction of prodromal AD in individual cases. Also, although these data offer important insights into the normal pathophysiology of the disease, the use of biomarkers to predict $\mathrm{AD}$ in the asymptomatic elderly is not warranted until registered drugs are available that offer a distinct disease-modifying effect combined with few side-effects. However, such biomarkers may be very useful in the immediate future for the design and evaluation of prevention trials by allowing one to enroll individuals who are still cognitively normal but are in the preclinical stage of the disease 
and, importantly, are within a few years of developing cognitive symptoms.

\section{NOVEL FLUID BIOMARKERS FOR AD}

There are numerous publications describing candidate CSF biomarkers other than $A \beta$ and tau, but initial promising results have most often not been reproduced (Table 1). Here, we review novel biomarkers that have shown promise in two independent studies, and shown a reasonable sensitivity and specificity for $\mathrm{AD}$. We also discuss some candidate biomarkers specifically related to A $\beta$ and APP metabolism.

\section{$\operatorname{sAPP} \beta$ and $\mathrm{sAPP} \alpha$}

During APP processing, the large aminoterminal domains of APP, sAPP $\alpha$, and sAPP $\beta$, are secreted into the extracellular space and eventually reach the CSF. In sporadic AD and MCI, CSF levels of both sAPP $\alpha$ and sAPP $\beta$ are unaltered or slightly increased (Olsson et al. 2003; Zetterberg et al. 2008; Lewczuk et al. 2010). Although there is no consistent change in sAPP levels in AD, these CSF biomarkers may be valuable tools in treatment trials to monitor an effect on APP processing.

\section{BACE1}

The major $\beta$-secretase responsible for $A \beta$ generation is $\beta$-site APP-cleaving enzyme 1 (BACE1). BACE1 expression and enzymatic activity are both increased in postmortem brains of patients with $\mathrm{AD}$ (Fukumoto et al. 2002; Yang et al. 2003). BACE1 can be measured in CSF, and its concentration and activity increase in $\mathrm{AD}$, preferentially in $\mathrm{MCI}$ cases with prodromal AD (Holsinger et al. 2004; Zhong et al. 2007; Zetterberg et al. 2008). These results suggest that up-regulation of BACE1 is an early pathogenic event in AD.

\section{$A \beta$ Oligomers}

Aggregation of soluble $A \beta$ to form insoluble fibrillar aggregates in plaques has long been regarded as the central pathogenic event in AD. However, recent results suggest that soluble
$A \beta$ oligomers inhibit long-term potentiation, the proposed biological substrate of memory, thereby playing a role in $\mathrm{AD}$ pathogenesis (Walsh and Selkoe 2007). Measurement of $A \beta$ oligomers in CSF may thus be an important core biomarker for AD. Some preliminary studies on $A \beta$ oligomers in CSF have been published. Using monoclonal antibodies for $\mathrm{A} \beta$ oligomers in an assay with PCR-based signal amplification, one study reported a marked increase in $\mathrm{AD}$ autopsy CSF (Georganopoulou et al. 2005). Flow cytometric results also suggest that $A \beta$ oligomers are present in CSF, but no information on the diagnostic utility of this assay has been presented (Santos et al. 2007). A weak band migrating at the size expected for $A \beta$ dimers appears in CSF immunoprecipitation experiments, utilizing an anti- $\mathrm{A} \beta$ antibody followed by SDS-PAGE and immunoblotting, but there is no clear correlation with $\mathrm{AD}$ (Klyubin et al. 2008). Immunoassays in which a monocloncal antibody is used for capture, and the same, biotinylated, antibody is used for detection, may be used to quantify protein aggregates, because monomers will not be detected since the epitope is already occupied by the capture antibody. Using ELISA methods based on this principle, higher CSF levels of $\mathrm{A} \beta$ oligomers were found in $\mathrm{AD}$ (Fukumoto et al. 2010). These promising results call for further studies, and need to be replicated in larger independent patient materials. It seems clear that although $A \beta$ oligomers are an attractive $\mathrm{AD}$ biomarker candidate, the level of such oligomers is very low compared with that of $A \beta$ monomers. Further, the identity of signals measured using different techniques must be verified by mass spectrometry.

\section{Other $\mathrm{A} \beta$ Isoforms}

$A \beta 40$ is the most abundant $A \beta$ isoform in CSF (Portelius et al. 2006a). Although there is no major change in the level of CSF A 440 in $A D$, and $A \beta 40$ levels do not correlate with amyloid load as evidenced by PIB binding (Fagan et al. $2006,2009 b)$, there is a marked decrease in the ratio of CSF $A \beta 42 / A \beta 40$ in $\mathrm{AD}$ and $\mathrm{MCI}$, which is more pronounced than the reduction in CSF 
Table 1. Fluid biomarkers for Alzheimer disease related to $\beta$-amyloid and tau pathology and neuronal degeneration

\begin{tabular}{|c|c|c|c|c|c|}
\hline Pathogenic process & Biomarker & Methodology & Change in $\mathrm{AD}$ & Stage of evaluation & Comment \\
\hline $\begin{array}{l}\mathrm{APP} / \mathrm{A} \beta \\
\text { metabolism and } \\
\text { plaque pathology }\end{array}$ & $\begin{array}{l}\mathrm{CSF} A \beta 42 \\
\text { and } \mathrm{A} \beta 40\end{array}$ & $\begin{array}{l}\text { Commercially available in several } \\
\text { different immunoassay formats. } \\
\text { Assay characteristics and } \\
\text { confounding factors well established }\end{array}$ & $\begin{array}{l}\text { Approximately } 50 \% \\
\text { reduction in CSF } A \beta 42 \\
\text { in } \mathrm{AD} \text { with dementia } \\
\text { and prodromal } \mathrm{AD} \\
\mathrm{CSF} \mathrm{A} \beta 42 / \mathrm{A} \beta 40 \text { ratio } \\
\text { may give slightly higher } \\
\text { accuracy than } \mathrm{A} \beta 42\end{array}$ & $\begin{array}{l}\text { Consistent results } \\
\text { from numerous } \\
\text { publications }\end{array}$ & $\begin{array}{l}\text { CSF A } \beta 42 \text { is the central CSF } \\
\text { biomarker for } A \beta \\
\text { metabolism } \\
\text { CSF A } \beta 42 \text { correlates with } \\
\text { amyloid load measured by } \\
\text { PIB-PET }\end{array}$ \\
\hline
\end{tabular}

\begin{tabular}{|c|c|}
\hline $\begin{array}{c}\text { Plasma } A \beta 42 \\
\text { and } A \beta 40\end{array}$ & $\begin{array}{l}\text { Commercially available in several } \\
\text { different immunoassay formats }\end{array}$ \\
\hline CSF A $\beta 16$ & $\begin{array}{l}\text { Immunoprecipitation combined with } \\
\text { MALDI-TOF mass spectrometry }\end{array}$ \\
\hline $\begin{array}{l}\text { CSF A } \beta \\
\text { oligomers }\end{array}$ & $\begin{array}{l}\text { Specialized techniques, e.g., } \\
\text { Bio-barcode PCR assay, western } \\
\text { blot, or high-sensitivity ELISA }\end{array}$ \\
\hline $\begin{array}{l}\text { CSF APP } \\
\text { isoforms } \\
\text { (sAPP } \alpha \\
\text { sAPP } \beta)\end{array}$ & Commercial assays available \\
\hline $\begin{array}{l}\text { CSF BACE1 } \\
\text { activity }\end{array}$ & $\begin{array}{l}\text { Different research assays used in } \\
\text { different publications }\end{array}$ \\
\hline
\end{tabular}

Brain $\mathrm{A} \beta$

turnover
Infusion of labeled leucine and continuous CSF sampling; immunoprecipitation, tryptic digestion and mass spectrometry measurement of total $A \beta$ accuracy than $A \beta 42$ alone

No consistent change in AD. Large overlap with healthy elderly

Consistent results from numerous publications

Increase in CSF $A \beta 16$ in $\mathrm{AD}$

Preliminary data. Needs verification using standard immunoassays

Increased level or increased Preliminary data. frequency of $A \beta$ oligomers in $\mathrm{AD}$

No change or slight increase in $\mathrm{AD}$ with large overlap with healthy elderly

Increase in $\mathrm{AD}$ with dementia and prodromal AD Needs verification using standard immunoassays

Needs further evaluation

Data based on publications using different methods

First study shows a decreased $A \beta$

Needs further evaluation
Plasma $A \beta 42$ and $A \beta 40$ has no diagnostic value for AD. May be valuable in clinical trials

Analysis of the $A \beta$ isoform pattern, including $A \beta 16$, may be of value in clinical trials on secretase inhibitors

The nature (dimers, trimers, dodecamers, high MW species) of $A \beta$ oligomers in CSF has to be determined

APP isoforms are not diagnostically useful, but may be valuable in clinical trials on, e.g., BACE1 inhibitors

The diagnostic value needs further evaluation. BACE1 activity may be useful in clinical trials on, e.g., BACE1 inhibitors

May be valuable to gauge $A \beta$ production and clearance in clinical drug trials 


\section{$\$_{\mathrm{CSH}}^{\infty}$ Cold Spring Harbor Perspectives in Medicine \\ Wo}

Table 1. Continued

\begin{tabular}{|c|c|c|c|c|c|}
\hline Pathogenic process & Biomarker & Methodology & Change in AD & Stage of evaluation & Comment \\
\hline \multirow[t]{2}{*}{$\begin{array}{l}\text { Tau phosphorylation } \\
\text { and tangle } \\
\text { pathology }\end{array}$} & CSF P-tau 181 & $\begin{array}{l}\text { Commercially available in different } \\
\text { immunoassay formats. } \\
\text { Assay characteristics and } \\
\text { confounding factors well established }\end{array}$ & $\begin{array}{l}\text { Increase in } \mathrm{AD} \text { with } \\
\text { dementia and } \\
\text { prodromal AD }\end{array}$ & $\begin{array}{l}\text { Consistent results } \\
\text { from numerous } \\
\text { publications }\end{array}$ & $\begin{array}{l}\text { CSF P-tau is the central CSF } \\
\text { biomarker for tau } \\
\text { phosphorylation state. } \\
\text { May be valuable as a } \\
\text { downstream biomarker in } \\
\text { anti-A } \beta \text { treatment trials }\end{array}$ \\
\hline & CSF P-tau231 & Commercial assay not available & $\begin{array}{l}\text { Increase in } \mathrm{AD} \text { with } \\
\text { dementia and } \\
\text { prodromal } \mathrm{AD}\end{array}$ & $\begin{array}{l}\text { Consistent results } \\
\text { from numerous } \\
\text { publications }\end{array}$ & $\begin{array}{l}\text { CSF P-tau is the central CSF } \\
\text { biomarker for tau } \\
\text { phosphorylation state. } \\
\text { May be valuable as a } \\
\text { downstream biomarker in } \\
\text { anti-A } \beta \text { treatment trials }\end{array}$ \\
\hline \multirow[t]{3}{*}{$\begin{array}{l}\text { Neuronal and axonal } \\
\text { degeneration }\end{array}$} & CSF T-tau & $\begin{array}{l}\text { Commercially available in different } \\
\text { immunoassay formats. } \\
\text { Assay characteristics and } \\
\text { confounding factors well established }\end{array}$ & $\begin{array}{l}\text { Increase in } \mathrm{AD} \text { with } \\
\text { dementia and } \\
\text { prodromal } \mathrm{AD}\end{array}$ & $\begin{array}{l}\text { Consistent results } \\
\text { from numerous } \\
\text { publications }\end{array}$ & $\begin{array}{l}\text { CSF T-tau is the central CSF } \\
\text { biomarker to monitor the } \\
\text { intensity of neuronal and } \\
\text { axonal degeneration in } \\
\text { treatment trials }\end{array}$ \\
\hline & CSF VILIP-1 & Single (research) assay & Increase in $\mathrm{AD}$ & $\begin{array}{l}\text { Needs further } \\
\text { evaluation }\end{array}$ & $\begin{array}{l}\text { CSF VLP-1 levels correlate with } \\
\text { CSF T-tau. May be a valuable } \\
\text { complementary biomarker } \\
\text { for axonal degeneration }\end{array}$ \\
\hline & $\begin{array}{l}\text { CSF NF } \\
\text { proteins }\end{array}$ & $\begin{array}{l}\text { Different (research) assays using in } \\
\text { different publications }\end{array}$ & $\begin{array}{l}\text { Normal in AD. } \\
\text { High CSF NF proteins } \\
\text { in disorders with } \\
\text { subcortical pathology, } \\
\text { e.g., VaD and NPH, and } \\
\text { in FTD }\end{array}$ & $\begin{array}{l}\text { Consistent results } \\
\text { from numerous } \\
\text { publications }\end{array}$ & $\begin{array}{l}\text { CSF NF proteins may be } \\
\text { valuable to differentiate } \mathrm{AD} \\
\text { from frontotemporal } \\
\text { dementia and subcortical } \\
\text { dementia disorders }\end{array}$ \\
\hline
\end{tabular}

Abbreviations: AD, Alzheimer disease; BACE1, $\beta$-site APP-cleaving enzyme 1; CSF, cerebrospinal fluid; FTD, frontotemporal dementia; NF, neurofilament; NPH, normal pressure hydrocephalus; PET, positron emission tomography; PIB, Pittsburgh compound B; P-tau, phosphorylated tau; T-tau, total tau; VaD, vascular dementia; VILIP-1, visinin-like protein 1. 
K. Blennow et al.

A 342 alone (Mehta et al. 2000; Hansson et al. 2007a). Apart from $A \beta 42$ and $A \beta 40$, other carboxy-terminally truncated $A \beta$ peptides can be identified in CSF, including $A \beta 37, A \beta 38$, and $A \beta 39$ (Lewczuk et al. 2003). The CSF level of $A \beta 38$ has been reported to be higher in $A D$, together with a decrease in the level of $A \beta 42$ (Lewczuk et al. 2003; Schoonenboom et al. 2005), suggesting that the $A \beta 42 / A \beta 38$ ratio may be used to improve diagnostic accuracy. The ratio of $A \beta 38 / A \beta 42$ has also been shown to positively correlate with PIB binding in nondemented cohorts (Fagan et al. 2009b), with an association that is slightly stronger than CSF A $\beta 42$ alone.

Several shorter carboxy-terminally truncated $\mathrm{A} \beta$ isoforms in CSF have also been identified and quantified by immunoprecipitation with an anti-A $\beta$ monoclonal antibody and Matrix-assisted laser desorption/ionization timeof-flight (MALDI-TOF) mass spectrometry (Portelius et al. 2006a). An increase in CSF $\mathrm{A} \beta 1-16$ is found in $\mathrm{AD}$ together with the expected decrease in $\mathrm{A} \beta 1-42$ (Portelius et al. 2006b, 2010). Data from experimental studies show that the shorter $A \beta$ isoforms $A \beta 1-14$, $A \beta 1-15$, and $A \beta 1-16$ are produced by a novel pathway for APP processing involving the concerted action of $\beta$ - and $\alpha$-secretase, whereas the longer isoforms, from $A \beta 1-17$ and up to $A \beta 1-$ 42 , are produced in the $\gamma$-secretase pathway (Portelius et al. 2009).

\section{Neuronal and Synaptic Degeneration}

Neuronal and synaptic proteins may prove valuable as CSF biomarkers because they provide information about cognitive function and disease progression. For example, visinin-like protein 1 (VILIP-1) is a highly expressed neuronal calcium sensor protein that was identified by gene array analyses designed to search for brain-specific protein biomarkers (Laterza et al. 2006). CSF VLP-1 increased markedly in $\mathrm{AD}$ in a clinical study, with a diagnostic performance similar to that of CSF tau and $A \beta$ (Lee et al. 2008). CSF levels of VLP-1 were higher in APOE ع4-positive cases, and correlated with Mini-Mental State Examination (MMSE) scores. A recent study of VILIP-1 showed that the ratio of VILIP-1/A $\beta 42$ was as good or better than tau/A $\beta 42$ in predicting progression from cognitively normal to very mild dementia (Tarawneh et al. 2011).

Neurofilament (NF) proteins are structural components of the neuronal axons. The expression of such proteins is particularly high in large myelinated axons (Friede and Samorajski 1970). Accordingly, high CSF levels of NF proteins are found in disorders with subcortical pathology, such as vascular dementia and normal-pressure hydrocephalus (Sjogren et al. 2001a; Agren-Wilson et al. 2007). CSF levels are also high in frontotemporal dementia, whereas they are normal in most cases of $\mathrm{AD}$ (Sjogren et al. 2000). CSF NF proteins may thus be valuable for differentiation between $\mathrm{AD}$, frontotemporal dementia, and subcortical dementia disorders.

Clinicopathologic studies have demonstrated that synaptic density is the variable that best correlates with cognitive performance (Terry et al. 1991). Thus, one might predict that synaptic proteins would be the class of biomarkers most tightly linked to cognition. Several pre- and postsynaptic proteins have been identified in CSF using a procedure based on protein precipitation followed by liquid-phase isoelectric focusing and western blotting. These proteins include rab3a, synaptotagmin, growthassociated protein (GAP-43), synaptosomalassociated protein (SNAP-25), and neurogranin (Davidsson et al. 1999). An immunoassay for GAP-43 showed that CSF levels are higher in $\mathrm{AD}$ patients than in controls and patients with frontotemporal dementia (Sjogren et al. 2001b). There are also positive correlations between CSF GAP-43 and T-tau, supporting the idea that both biomarkers reflect axonal and synaptic degeneration.

\section{Inflammation and Oxidative Stress}

Neuroinflammation, in the way of glial activation (especially in the vicinity of amyloid plaques), is a robust but nonspecific feature of AD. A number of reports published in the 1990s and early 2000s describe alterations in the levels 
of various inflammatory and signaling molecules, as well as markers of oxidative stress (e.g., $\alpha 1$-antichymotrypsin, isoprostane, the interleukins, TNF $\alpha$, interferon- $\gamma$, complement C1q, and TGF- $\beta$ ) in AD CSF (Zetterberg et al. 2004; Craig-Schapiro et al. 2009). However, results have been very inconsistent, probably owing to methodological differences (e.g., in the procedures for CSF collection and processing, assay differences, and criteria used for subject ascertainment), prevalence of comorbidities in the studied cohorts, and methods of diagnosis. Unbiased proteomics methods have more recently been used to identify molecules that differ between AD and control CSF (and serum and plasma). These studies have consistently identified a plethora of inflammatory markers that differ in abundance between clinical groups (Castano et al. 2006; Finehout et al. 2007). However, even in these unbiased screens, the direction of reported difference in abundance has not been consistent. Despite this, one astrocyte marker, YKL-40, discovered in an unbiased proteomic screen, has recently been validated in a large cohort of cognitively normal and $\mathrm{AD}$ subjects to be increased in $\mathrm{AD}$ and to predict clinical worsening from cognitively normal to very mild dementia (CraigShapiro et al. 2010). The recent availability of commercial multiplexed assays should permit analysis of a large panel of inflammatory and signaling molecules in large-scale studies. It is conceivable (and probable) that adding markers of neuroinflammation to the other CSF markers (such as $\mathrm{A} \beta 42$, tau, and P-tau) will further strengthen diagnostic and prognostic capability (Hu et al. 2010).

$\mathrm{AD}$ pathogenesis also includes free radicalmediated injury to neurons. Lipid peroxidation is an important consequence of such damage, and it generates many products, including F2-isoprostanes. These molecules may serve as biomarkers for this pathogenic process. CSF F2-isoprostane levels have been reported to be increased in AD (Montine et al. 2007). Recent studies also show an increase in F2-isoprostanes in MCI cases with prodromal AD (Brys et al. 2009a) and in asymptomatic carriers of FAD mutations (Ringman et al. 2008). In contrast, studies on F2-isoprostanes in plasma have reported conflicting results, probably because the contribution of brain-derived F2-isoprostanes to plasma is clouded by the much larger contribution of peripherally derived F2-isoprostanes (Montine et al. 2007).

\section{SILK Technology}

Recently a new in vivo technique, known as Stable Isotope Labeling Kinetics (SILK), has been developed to measure the production and clearance rates of CNS proteins in humans (Figure 3 ). In this technique, a stable (nonradioactive) isotope-labeled amino acid (e.g., ${ }^{13} \mathrm{C}_{6}$-leucine) is administered intravenously and becomes incorporated into newly synthesized proteins. CSF (and plasma) can then be sampled over time via intrathecal and intravenous catheters, respectively. Using mass spectrometry to compare the amounts of labeled versus unlabeled proteins over time, very precise synthesis, clearance, and dose-response curves can be developed. This technique was first applied to determine the synthesis and clearance rates of $A \beta$ in the CNS (Bateman et al. 2006). The fractional production and clearance rates of $A \beta$ in vivo was found to be extremely rapid $(7.6 \%$ per hr and $8.3 \%$ per hr, respectively), with absolute concentrations in the CSF varying widely between sampling times. This technique was used more recently in a randomized, double-blind, placebo-controlled study to demonstrate the pharmacokinetic/pharmacodynamic relationship between an $A \beta$ synthesis inhibitor and the absolute rate of CNS A $\beta$ synthesis (Bateman et al. 2009). In addition, this method identified slower fractional $A \beta$ clearance with no change in fractional $A \beta$ synthesis in late-onset $A D$ versus age-matched controls (Mawuenyega et al. 2010). Since this technique automatically labels all newly synthesized proteins, its potential lies in the fact that it allows for the evaluation of other proteins relevant to $\mathrm{AD}$, other neurodegenerative diseases, and the metabolism of multiple biomarkers simultaneously. As such, this technology may uncover robust fluid biomarkers that will be useful for assessing disease risk, improving $\mathrm{AD}$ diagnosis and prognosis, 
K. Blennow et al.

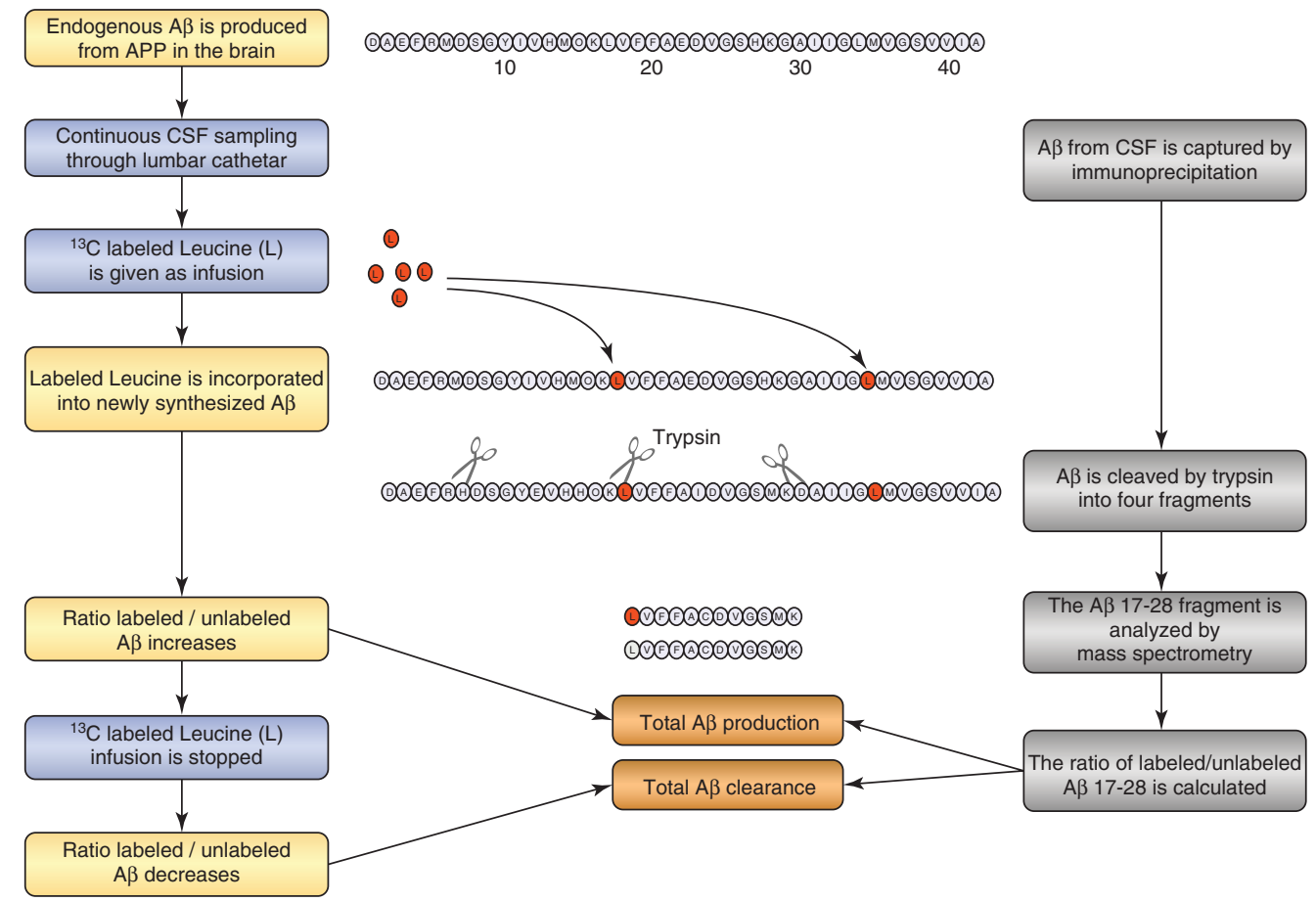

Figure 3. Schematic drawing of the principles for the stable isotope labeling kinetics technology for measuring the production and clearance of total $\beta$-amyloid $(A \beta)$ in the brain.

tracking disease progression, and evaluating treatment efficacy.

\section{Plasma Biomarkers}

Efforts to find reliable biomarkers for $\mathrm{AD}$ in peripheral blood have had little success. Several candidate blood biomarkers have been proposed, but have been difficult to verify in independent studies. In this review we focus on plasma $A \beta$, which is the most extensively examined peripheral biomarker for $\mathrm{AD}$. We also review some explorative pilot studies with promising results.

Many studies have examined plasma $A \beta$ as a biomarker for $\mathrm{AD}$, but the findings are contradictory. Some groups report slightly higher plasma levels of either $A \beta 42$ or $A \beta 40$ in $A D$, although with a broad overlap between patients and controls, whereas most studies find no change (Irizarry 2004). Studies examining the value of plasma $A \beta$ in predicting $A D$ in the cognitively normal elderly also show a very broad overlap in plasma $A \beta 42$ and $A \beta 40$ levels. Some studies report that high plasma $A \beta 42$, or a high $A \beta 42 / A \beta 40$ ratio, is a risk indicator for future $\mathrm{AD}$, whereas others report the opposite (Mayeux et al. 2003; Pomara et al. 2005; van Oijen et al. 2006; Graff-Radford et al. 2007). These discouraging results are probably due to the fact that the majority of plasma $A \beta$ is derived from peripheral tissues, and does not reflect brain $\mathrm{A} \beta$ turnover or metabolism (Mehta et al. 2000). This is consistent with a lack of correlation between plasma $A \beta$ species and brain amyloid load as determined by PIB binding (Fagan et al. 2006, 2009b). It is possible, however, that the hydrophobic nature of $A \beta$ causes it to bind to plasma proteins, which may result in epitope masking and other analytical interferences (Kuo et al. 1999).

There are some recent reports that present promising novel blood biomarkers for AD. Combined multivariate analysis of 18 plasma signaling and inflammatory proteins was found to identify $\mathrm{AD}$ patients and predict future $\mathrm{AD}$, 
with high accuracy, in MCI patients (Ray et al. 2007). This protein panel was identified after screening a large number of known proteins using a filter-based protein array. Further independent studies are needed to verify if this panel is the optimal combination of plasma biomarkers, as well as to determine their diagnostic value. Another study using explorative proteomics technology identified $\mathrm{AD}$-associated changes in the plasma levels of complement factor $\mathrm{H}$ and $\alpha 2$-macroglobulin (Hye et al. 2006). This finding was replicated using semiquantitative immunoblotting techniques. A significant change was also reported in the ratio of the microcirculation regulating factor midregional pro-atrial natriuretic peptide to carboxy-terminal endothelin-1 precursor fragment, both of which regulate microcirculation, in plasma from AD patients (Buerger et al. 2009). If replicated in independent studies using immunoassay techniques suitable for routine diagnostic laboratories, these types of plasma protein panels may serve as useful screening tests for $\mathrm{AD}$.

\section{FLUID BIOMARKERS IN CLINICAL TRIALS}

In addition to their potential as tools for clinical diagnosis, CSF biomarkers may be valuable in drug development in at least four different ways. These uses are as diagnostic markers for the enrichment of AD cases, for patient stratification, as safety markers, and as detectors and monitors of biochemical drug effects (Table 2).

\section{Improved Diagnosis/Enrichment of AD Cases}

Diagnosing early $\mathrm{AD}$ is a great challenge for clinicians because MCI cases only have a mild disturbance in episodic memory and executive dysfunction, whereas other specific symptoms are lacking or are vague and indistinct. The only clinical method available to determine which MCI patients have prodromal $\mathrm{AD}$ is an extended follow-up period. Indeed, even at specialized academic centers, the accuracy of the clinical diagnosis of $\mathrm{AD}$ in cases that have been followed clinically for several years can be relatively low, with sensitivity and specificity figures of $70-80 \%$ (Knopman et al. 2001).
These figures are considerably lower in patients with early AD (Visser et al. 2005) and in primary care settings (Ganguli et al. 2004). Assessment of cognitive changes within individuals over a number of years (as determined with semistructured interviews with the patient and a reliable collateral source who knows the patient well, such as a spouse or adult child), can increase diagnostic accuracy (Storandt et al. 2006). However, this laborious approach is probably not feasible in primary care settings.

Clinical MCI trials of cholinesterase inhibitors, in which having a reduced conversion rate to $\mathrm{AD}$ was used as a clinical endpoint, have failed to find any significant benefit of the drugs (Raschetti et al. 2007). These trials have recruited unselected MCI cases, meaning that approximately half of the cases do not have prodromal AD, and thus will not convert. This may have adversely affected the possibility of detecting any positive clinical effect of the drug (Cummings et al. 2007). Addition of positive CSF biomarkers as inclusion criteria in MCI and even prevention trials will increase the proportion of subjects with underlying $\mathrm{AD}$ pathology and thereby increase the possibility of detecting a positive effect of the drug.

\section{Stratification of AD Cases Based on Biomarker Data}

It is well established that $\mathrm{AD}$ is a heterogeneous disorder, at both the clinical and neuropathological levels (Blennow et al. 2006). It is quite possible that the effects of proposed diseasemodifying drugs will differ between subgroups of $\mathrm{AD}$ patients with respect to degree of plaque and tangle pathology (as evidenced by biomarkers) or genetic determinants. As an example, passive immunization was reported to differ both in treatment effect and side-effects between $A P O E$ \&4 carriers and noncarriers (Salloway et al. 2009).

Since CSF biomarkers reflect the central pathogenic processes in $\mathrm{AD}$, they may be used in post-hoc analyses to stratify the patient cohort in clinical trials. For example, one could postulate that a patient subgroup with a certain biomarker trait, such as low CSF A $\beta 42$ 
K. Blennow et al.

Table 2. Use of fluid biomarkers in Alzheimer disease clinical trials

\begin{tabular}{|c|c|c|c|}
\hline Application & Rationale & Time point for use & Comment \\
\hline $\begin{array}{l}\text { Enrichment of } \\
\text { AD cases }\end{array}$ & $\begin{array}{l}\text { CSF biomarkers may be } \\
\text { valuable in clinical trials } \\
\text { on early } \mathrm{AD} \text { or } \mathrm{MCI} \text {, to } \\
\text { improve the diagnostic } \\
\text { accuracy and enrich the } \\
\text { patient sample with } \\
\text { genuine } \mathrm{AD} \text { cases }\end{array}$ & $\begin{array}{l}\text { Baseline evaluation } \\
\text { of CSF biomarkers } \\
\text { in cases eligible for } \\
\text { the trial }\end{array}$ & $\begin{array}{l}\text { High T-tau and P-tau and low } A \beta 42 \text { are } \\
\text { indicative of } A D\end{array}$ \\
\hline $\begin{array}{l}\text { Post-hoc patient } \\
\text { stratification }\end{array}$ & $\begin{array}{l}\text { AD cases with biomarker } \\
\text { evidence of a clear } \\
\text { disturbance in the } \mathrm{A} \beta \\
\text { metabolism may have a } \\
\text { more clear-cut effect of } \\
\text { anti-A } \beta \text { disease- } \\
\text { modifying drugs }\end{array}$ & $\begin{array}{c}\text { Post-hoc stratification } \\
\text { of AD cases based } \\
\text { on baseline CSF } \\
\text { biomarker data }\end{array}$ & $\begin{array}{l}\text { CSFA } 442 \text { may be valuable to stratify AD } \\
\text { cases enrolled in a trial on an anti-A } \beta \\
\text { disease-modifying drug candidate } \\
\text { CSF P-tau may be valuable to stratify AD } \\
\text { cases enrolled in a trial on a drug } \\
\text { targeting tau phosphorylation and } \\
\text { tangle pathology }\end{array}$ \\
\hline $\begin{array}{l}\text { Safety } \\
\text { monitoring }\end{array}$ & $\begin{array}{l}\text { CSF biomarkers may, } \\
\text { together with MRI } \\
\text { scans, be used to } \\
\text { identify cases with } \\
\text { meningoencephalitis or } \\
\text { vasogenic edema in } A \beta \\
\text { immunotherapy clinical } \\
\text { trials }\end{array}$ & $\begin{array}{l}\text { Baseline evaluation } \\
\text { CSF biomarkers to } \\
\text { allow comparison } \\
\text { with a CSF sample } \\
\text { taken in the case of } \\
\text { an adverse event }\end{array}$ & $\begin{array}{l}\text { CSF cell count, IgG/IgM index, and } \\
\text { IgG/IgM oligoclonal bands are } \\
\text { standard measures to identify and } \\
\text { monitor an inflammatory process, } \\
\text { such as meningoencephalitis, within } \\
\text { the CNS } \\
\text { CSF/serum albumin ratio is the } \\
\text { standard measure to identify and } \\
\text { monitor a disturbance in the blood- } \\
\text { brain barrier causing cerebral edema }\end{array}$ \\
\hline $\begin{array}{l}\text { Monitoring of } \\
\text { drug activity } \\
\text { on pathogenic } \\
\text { processes }\end{array}$ & $\begin{array}{l}\text { CSF biomarkers may } \\
\text { provide information } \\
\text { that the drug has an } \\
\text { effect on a specific } \\
\text { pathogenic process } \\
\text { directly in patients with } \\
\text { AD }\end{array}$ & $\begin{array}{l}\text { Evaluation of CSF } \\
\text { biomarkers in } \\
\text { samples taken at } \\
\text { baseline compared } \\
\text { with samples taken } \\
\text { at time points } \\
\text { during the trial, } \\
\text { including the last } \\
\text { week of the trial }\end{array}$ & $\begin{array}{l}\text { Primary CSF biomarkers for APP/A } \beta \\
\text { metabolism (e.g., A } \beta 42 \text {, sAPP } \beta \text {, } \\
\text { BACE1 activity, and A } \beta \text { turnover) may } \\
\text { give biochemical evidence for the } \\
\text { specific effect of an anti-A } \beta \text { drug } \\
\text { candidate. } \\
\text { Downstream CSF biomarkers (e.g., } \\
\text { P-tau and T-tau) may give } \\
\text { biochemical evidence for downstream } \\
\text { effects on tangle pathology and axonal } \\
\text { degeneration of an anti-A } \beta \text { drug } \\
\text { candidate }\end{array}$ \\
\hline
\end{tabular}

Abbreviations: AD, Alzheimer disease; APP, amyloid precursor protein; CSF, cerebrospinal fluid; MCI, mild cognitive impairment; T-tau, total tau; P-tau, phosphorylated tau.

indicating plaque pathology, will show a better effect of anti-A $\beta$ disease-modifying drugs than a subgroup with normal CSF A $\beta 42$ levels.

\section{Safety Monitoring}

Trials of the new type of disease-modifying treatments have been hampered by side-effects including meningoencephalitis, which was observed in a subset of cases in the AN-1792 trial on active $\mathrm{A} \beta$ immunotherapy, and vasogenic edema, which was observed in the AAB001 trial of passive immunotherapy (Orgogozo et al. 2003; Salloway et al. 2009). CSF analysis is the standard method to diagnose both encephalitis and blood-brain barrier damage associated with disorders that cause edema (Tibbling et al. 1977; Andersson et al. 1994). It is also possible to use the baseline CSF sample to initially identify and exclude cases with chronic infectious or 
inflammatory CNS disorders that may mimic $\mathrm{AD}$, such as neuroborreliosis (Andreason et al. 2010). The inclusion of such cases in a clinical trial might result in the erroneous conclusion that a side-effect, such as encephalitis, has occurred. Further, if a baseline CSF sample is taken for comparison before active therapy is initiated, it can be used to identify even minor inflammatory activation within the CNS that is due to side-effects of the drug, thus permitting safety monitoring in clinical trials. Lastly, biomarkers may also be valuable in demonstrating the absence of side-effects, such as immune activation, in longitudinal CSF samples during treatment.

\section{Monitoring the Biochemical Effect of a Drug}

The effects of disease-modifying anti-A $\beta$ drugs on plaque pathology are commonly evaluated in AD transgenic mice, but these animal models have had a low predictive power for treatment success in patients with sporadic AD (Blennow et al. 2006). To bridge the gap between animal studies and large clinical trials, evidence for a true effect on AD pathogenesis directly in man would help in selecting the most promising drug candidates.

In slowly progressive disorders such as $\mathrm{AD}$, evaluation of the clinical effect of a drug using rating scales requires large patient materials and extended treatment periods. For drugs with a symptomatic effect, such as cholinesterase inhibitors, an early improvement in cognitive function is expected. In contrast, a disease-modifying drug cannot be expected to have an early effect on symptoms, but will instead lead to a less pronounced decline in cognitive function over years. Thus, the number of patients needed to detect a disease-modifying effect on cognition is probably larger, and the treatment period longer, than for a symptom-modifying drug.

Biomarkers used to identify and monitor the biochemical effect of drugs are known as "theragnostic markers" (Blennow et al. 2010). Such markers may be used to identify and monitor both the specific effect of a drug on its intended target and its effect on downstream pathogenic events. A trial that uses such markers would probably require relatively small amounts of patient materials and short treatment periods. Such a strategy may be particularly suitable for making a go/no-go decision for large and expensive phase II or III clinical trials. This approach is feasible given results from longitudinal studies demonstrating low intra-individual variability of CSF T-tau, P-tau, and A $\beta 42$ levels over time (Blennow et al. 2007; Zetterberg et al. 2007). Some of these biomarkers might also serve as substitutes (proxies) for clinical endpoints. However, fullscale clinical trials will be required to determine whether this is possible. Lastly, for regulatory purposes, a claim for a disease-modifying effect can only be made when a drug has been proven to have both an effect on cognition and biomarker evidence of an effect on the central pathogenic processes (Siemers 2009; Vellas 2009). To date, there are only preliminary reports suggesting that CSF biomarkers may be useful as theragnostic markers. Importantly, drug candidates with no proven effect on the molecular pathogenesis of $\mathrm{AD}$, such as cholinesterase inhibitors and lithium, have no effect on AD CSF core biomarkers (Blennow et al. 2007; Hampel et al. 2009). Nevertheless, data from animal studies show that treatment with $\gamma$-secretase inhibitors results in a reduction of cortical, CSF, and plasma levels of A $\beta$ (Lanz et al. 2004; Anderson et al. 2005). Similarly, treatment in monkeys with a BACE1 inhibitor results in a reduction in CSF $A \beta 42, A \beta 40$, and sAPP $\beta$ levels (Sankaranarayanan et al. 2009). In $\mathrm{AD}$ cases, it is uncertain how CSF $\mathrm{A} \beta$ may respond to treatment with efficacious anti-A $\beta$ drugs. In a phase IIa study of the $A \beta$ clearance-enhancing compound PBT2, a significant dose-dependent reduction in CSF A $\beta 42$ levels during treatment was observed (Lannfelt et al. 2008). Results from a clinical study on the amyloid-targeting drug phenserine also suggest that CSF A $\beta$ levels as a biomarker may be valuable for evaluating treatment effects (Kadir et al. 2008). However, in the interrupted phase IIa AN1792 trial, no significant effect was found on CSF A $\beta 42$, despite a decrease toward normal levels of the downstream biomarker T-tau (Gilman et al. 2005). A clinical study of $\gamma$-secretase 
K. Blennow et al.

inhibitor treatment also failed to find any effect on CSF A 42 levels (Fleisher et al. 2008). Nevertheless, this drug has a clear inhibitory effect on the $A \beta$ production rate, as can be seen when evaluating its effect by measuring the isotopelabeled $\mathrm{A} \beta$ ratio in CSF; a clear inhibitory effect on the rate of $A \beta$ production was observed (Bateman et al. 2009). Several other clinical trials of disease-modifying drug candidates that include biomarkers as endpoints are currently ongoing. These trials will provide further evidence of whether biomarkers will be useful as proof-of-concept tools for the mechanism of action of the drug, and as surrogate markers to predict clinical outcome.

\section{FLUID BIOMARKERS AS ENDOPHENOTYPES IN GENETIC STUDIES}

Just as CSF biomarker data from well-characterized, longitudinally followed cohorts may be used to guide diagnosis and estimate prognosis, it can also be used to identify genetic markers that are associated with $\mathrm{AD}$ risk. Compared with typical genetic studies of $\mathrm{AD}$ that rely on less precise clinical diagnoses, genetic studies based on quantitative endophenotype data can provide more power. In support of this approach, recent studies have shown that elevated CSF T-tau and P-tau levels are associated with single nucleotide polymorphisms in the MAPT gene (from which tau protein is produced; Kauwe et al. 2008). Likewise, CSF A $\beta$ levels have been found to associate with polymorphisms in several genes (Kauwe et al. 2009). In this way, by "converting" endophenotype data derived from fluid biomarkers to novel genetic biomarkers, it may be possible to identify individuals at greater risk of developing $\mathrm{AD}$ and, in the near future, provide treatment options prior to the development of any $\mathrm{AD}$ pathology.

\section{FUTURE PERSPECTIVES}

Overlapping Pathology Influences Diagnostic Biomarker Accuracy

Currently available biomarkers are not perfect in diagnostic accuracy. However, except for technical shortcomings with the biomarkers, there are several fundamental reasons for why a $100 \%$ sensitive and specific biomarker for $\mathrm{AD}$ is an unreachable goal. First, most biomarker studies are based on clinically diagnosed cases, which introduces a relatively large percentage of misdiagnosis (Forman et al. 2006; Engelborghs et al. 2008). Second, a significant percentage of nondemented elderly have enough plaques and tangles to warrant a neuropathological diagnosis of AD (Snowdon 1997; Price and Morris 1999). Third, there is a large overlap in pathology between $\mathrm{AD}$ and other dementias, such as Lewy body dementia and vascular dementia (Jellinger 1996; Kotzbauer et al. 2001; Schneider et al. 2009). This overlap in pathology essentially precludes the possibility of finding biomarkers that have close to $100 \%$ sensitivity and specificity for $\mathrm{AD}$. One way out of this catch 22-like situation might be to reconsider the terminology. Instead of using the term "AD biomarkers," we could acknowledge that the biomarkers reflect distinct pathogenic or pathologic processes, for example, amyloid retention in the brain and degeneration of nonmyelinated cortical axons. These changes, especially in combination, are frequently seen in $\mathrm{AD}$ but may also be present in other neurodegenerative disorders, especially in isolation.

\section{Combination of Multiple Biomarker Modalities}

It is logical to suppose that the combination of CSF biomarkers with both structural (CT/MRI) and functional (SPECT/PET) brain imaging will increase the diagnostic accuracy as compared with the use of one biomarker alone. However, only a few studies to date have directly examined this issue. Positive CSF biomarkers combined with either CTor MRI measurements of medial temporal lobe atrophy have been found to increase the accuracy of an AD diagnosis (Schoonenboom et al. 2008; Zhang et al. 2008; Brys et al. 2009b). A recent study also showed that the combination of positive CSF biomarkers with the degree of structural ADlike abnormalities as shown by MRI improved prediction of the conversion from amnestic $\mathrm{MCI}$ to $\mathrm{AD}$ better than either biomarker alone 
(Vemuri et al. 2009). Similarly, combining positive CSF biomarkers with an evaluation of regional cerebral blood flow using either the 133Xe method or SPECT has been shown to improve the accuracy of a prodromal AD diagnosis above that achieved with either biomarker alone (Okamura et al. 2002; Hansson et al. 2007b). Further, although no study has examined the added diagnostic value of PIB-PET and CSF biomarkers, there is a strict negative correlation between the degree of PIB binding as seen in PET images and the CSF level of A 342 (Fagan et al. 2006, 2009b; Forsberg et al. 2008; Grimmer et al. 2009). The relationship between PIB binding and the tau/Aß42 and ptau/A $\beta$ ratios is even stronger than for $A \beta 42$ alone (Fagan et al. 2011). Large multicenter studies are needed to further define the added diagnostic value of combining multiple biomarker modalities. Such studies will also provide information on the optimal brain region to evaluate for atrophy by MRI or A $\beta$ load by PET. Complementary data are also needed to evaluate whether new high-resolution MRI scanners and newly developed amyloid ligands, such as AZD2184 and AV-45, will improve diagnostic sensitivity and specificity (Choi et al. 2009; Nyberg et al. 2009).

\section{Novel Research Criteria for AD}

The current clinical diagnostic criteria for $\mathrm{AD}$ were outlined more than 25 years ago by the National Institute of Neurological and Communicative Disorders and Stroke and the Alzheimer Disease and Related Disorders (NINCDS-ADRDA) Work Group. They depend largely on the exclusion of causes other than $\mathrm{AD}$ for dementia (McKhann et al. 1984). These criteria state that a diagnosis of $\mathrm{AD}$ cannot be made until the patient has dementia, which is defined as "cognitive symptoms severe enough to interfere with social or occupational activities." The DSM-IV and ICD-10 criteria, which are used for routine diagnosis, also require that a patient demonstrate dementia before a diagnosis of AD is possible (WHO 1992; American Psychiatric Association 2000). If the new disease-modifying drugs prove to be effective and become clinically available, these present criteria will hinder patients in the early stages of the disease, certainly in the preclinical stage, from receiving effective therapy.

For this reason, new criteria for different stages of $\mathrm{AD}$ have recently been suggested (Dubois et al. 2007; Albert et al. 2011; McKhann et al. 2011; Sperling et al. 2011). These criteria have been constructed to permit a diagnosis of $\mathrm{AD}$ in earlier stages of the disease, and are centered on the clinical identification of episodic memory impairment together with one or more abnormal biomarkers, including MRI, PET, and CSF markers. More detailed guidelines are needed to establish how the use of biomarkers can be implemented in the diagnostic procedure for early $\mathrm{AD}$ to be used in clinical practice. For example, details are needed regarding the scale that should be applied to measure memory impairment, which assays and cutoffs to use for CSF biomarkers, which brain region (whole brain, hippocampus, or entorhinal cortex) to use to evaluate brain atrophy by MRI, which amyloid ligand to use, and which brain region to use to evaluate brain $A \beta$ load by PET. Studies on these issues are just beginning to emerge (Frisoni et al. 2009). Biomarker assays also need to be standardized between laboratories and centers to allow for general implementation of cutoff points in the diagnostic algorithms. As a first step in this direction, a global quality control program for CSF biomarkers was recently launched. This program also covers practical details on lumbar puncture and CSF sample processing (Blennow et al. 2010). Results from the first two rounds in this quality control program have recently been presented.

\section{CONCLUSION}

There is an enormous amount of literature showing good or excellent diagnostic performance of several biomarkers reflecting different facets of the disease process in $\mathrm{AD}$. We have unprecedented possibilities to be able to phenotype our patients. Now is the time to develop the biomarker-based research criteria proposed by Dubois et al. (2007), into a detailed, practical 
K. Blennow et al.

and feasible diagnostic algorithm that will be applicable in clinics worldwide. It is easy to predict that this will be a challenging process. The proposed algorithm would need evaluation in a longitudinal clinical multicenter study to assess its diagnostic accuracy against postconversion clinical dementia diagnoses and, whenever possible, neuropathological findings before general implementation in the clinic.

\section{REFERENCES}

Agren-Wilsson A, Lekman A, Sjoberg W, Rosengren L, Blennow K, Bergenheim AT, Malm J. 2007. CSF biomarkers in the evaluation of idiopathic normal pressure hydrocephalus. Acta Neurol Scand 116: 333-339.

Albert MS, Dekosky ST, Dickson D, Dubois B, Feldman HH, Fox NC, Gamst A, Holtzman DM, Jagust WJ, Petersen RC, et al. 2011. The diagnosis of mild cognitive impairment due to Alzheimer's disease: Recommendations from the National Institute on Aging-Alzheimer's Association workgroups on diagnostic guidelines for Alzheimer's disease. Alzheimer's Dement 7: 270-279.

American Psychiatric Association. 2000. Diagnostic and statistical manual of mental disorders (IV-TR), 4th ed. American Psychiatric Association, Washington, DC.

Anderson JJ, Holtz G, Baskin PP, Turner M, Rowe B, Wang B, Kounnas MZ, Lamb BT, Barten D, Felsenstein K, et al. 2005. Reductions in $\beta$-amyloid concentrations in vivo by the $\gamma$-secretase inhibitors BMS-289948 and BMS299897. Biochem Pharmacol 69: 689-698.

Andersson M, Alvarez-Cermeño J, Bernardi G, Cogato I, Fredman P, Frederiksen J, Fredrikson S, Gallo P, Grimaldi LM, Grønning M, et al. 1994. Cerebrospinal fluid in the diagnosis of multiple sclerosis: A consensus report. J Neurol Neurosurg Psychiat 57: 897-902.

Andreasen N, Blennow K, Zetterberg H. 2010. Neuroinflammation screening in immunotherapy trials against Alzheimer's disease. Int J Alzheimers Dis 2010: 638379.

Bateman RJ, Munsell LY, Morris JC, Swarm R, Yarasheski KE, Holtzman DM. 2006. Human amyloid- $\beta$ synthesis and clearance rates as measured in cerebrospinal fluid in vivo. Nat Med 12: 856-861.

Bateman RJ, Siemers ER, Mawuenyega KG, Wen G, Browning KR, Sigurdson WC, Yarasheski KE, Friedrich SW, Demattos RB, May PC, et al. 2009. A $\gamma$-secretase inhibitor decreases amyloid- $\beta$ production in the central nervous system. Ann Neurol 66: 48-54.

Bian H, Van Swieten JC, Leight S, Massimo L, Wood E, Forman M, Moore P, de Koning I, CLark CM, Rosso S, et al. 2008. CSF biomarkers in frontotemporal lobar degeneration with known pathology. Neurology 70: 1827-1835.

Blennow K. 2004. Cerebrospinal fluid protein biomarkers for Alzheimer's disease. NeuroRx 1: 213-225.

Blennow K. 2005. CSF biomarkers for Alzheimer's disease: Use in early diagnosis and evaluation of drug treatment. Expert Rev Mol Diagn 5: 661-672.

Blennow K, Hampel H. 2003. CSF markers for incipient Alzheimer's disease. Lancet Neurol 2: 605-613.
Blennow K, Wallin A, Agren H, Spenger C, Siegfried J, Vanmechelen E. 1995. Tau protein in cerebrospinal fluid: A biochemical marker for axonal degeneration in Alzheimer disease? Mol Chem Neuropathol 26: 231-245.

Blennow K, de Leon MJ, Zetterberg H. 2006. Alzheimer's disease. Lancet 368: 387-403.

Blennow K, Zetterberg H, Minthon L, Lannfelt L, Strid S, Annas P, et al. 2007. Longitudinal stability of CSF biomarkers in Alzheimer's disease. Neurosci Lett 419: 18-22.

Blennow K, Hampel H, Weiner M, Zetterberg H. 2010. Cerebrospinal fluid and plasma biomarkers in Alzheimer disease. Nat Rev Neurol 6: 131-144.

Blom ES, Giedraitis V, Zetterberg H, Fukumoto H, Blennow $\mathrm{K}$, Hyman BT, Irizarry MC, Wahlund LO, Ingelsson M. 2009. Rapid progression from mild cognitive impairment to Alzheimer's disease in subjects with elevated levels of tau in cerebrospinal fluid and the APOE $\varepsilon 4 / \varepsilon 4$ genotype. Dement Geriatr Cogn Disord 27: 458-464.

Brys M, Pirraglia E, Rich K, Rolstad S, Mosconi L, Switalski R, Glodzik-Sobanska L, De Santi S, Zinkowski R, Mehta P, et al. 2009a. Prediction and longitudinal study of CSF biomarkers in mild cognitive impairment. Neurobiol Aging 30: 682-690.

Brys M, Glodzik L, Mosconi L, Switalski R, De Santi S, Pirraglia E, Rich K, Kim BC, Mehta P, Zinkowski R, et al. 2009b. Magnetic resonance imaging improves cerebrospinal fluid biomarkers in the early detection of Alzheimer's disease. J Alzheimer's Dis 16: 351-362.

Buerger K, Ewers M, Pirttila T, Zinkowski R, Alafuzoff I, Teipel SJ, DeBernardis J, Kerkman D, McCulloch C, Soininen $\mathrm{H}$, et al. 2006. CSF phosphorylated tau protein correlates with neocortical neurofibrillary pathology in Alzheimer's disease. Brain 129: 3035-3041.

Buerger K, Ernst A, Ewers M, Uspenskaya O, Omerovic M, Morgenthaler NG, Knauer K, Bergmann A, Hampel H. 2009. Blood-based microcirculation markers in Alzheimer's disease-diagnostic value of midregional proatrial natriuretic peptide/C-terminal endothelin-1 precursor fragment ratio. Biol Psychiat 65: 979-984.

Cairns NJ, Ikonomovic MD, Benzinger T, Storandt M, Fagan AM, Shah AR, et al. 2009. Absence of Pittsburgh compound $\mathrm{B}$ detection of cerebral amyloid $\beta$ in a patient with clinical, cognitive, and cerebrospinal fluid markers of Alzheimer disease: A case report. Arch Neurol 66: 1557-1562.

Castano EM, Roher AE, Esh CL, Kokjohn TA, Beach T. 2006. Comparative proteomics of cerebrospinal fluid in neuropathologically-confirmed Alzheimer's disease and non-demented elderly subjects. Neurol Res 28: 155-163.

Choi SR, Golding G, Zhuang Z, Zhang W, Lim N, Hefti F, Benedum TE, Dilbourn MR, Skovronsky D, Kung HF. 2009. Preclinical properties of 18F-AV-45: A PET agent for A $\beta$ plaques in the brain. J Nucl Med 50: 1887-1894.

Clark CM, Xie S, Chittams J, Ewbank D, Peskind E, Galasko D, Morris JC, McKeel DW Jr, Farlow M, Weitlauf SL, et al. 2003. Cerebrospinal fluid tau and $\beta$-amyloid: How well do these biomarkers reflect autopsy-confirmed dementia diagnoses? Arch Neurol 60: 1696-1702.

Craig-Schapiro R, Fagan AM, Holtzman DM. 2009. Biomarkers of Alzheimer's disease. Neurobiol Dis 35: 128-140.

Craig-Schapiro R, Perrin RJ, Roe CM, Xiong C, Carter D, Cairns NJ, Mintun MA, Peskind ER, Li F, Galasko DR, 
et al. 2010. YKL-40: A novel prognostic fluid biomarker for preclinical Alzheimer's disease. Biol Psychiat 68, 903-912.

Cummings JL, Doody R, Clark C. 2007. Disease-modifying therapies for Alzheimer disease: Challenges to early intervention. Neurology 69: 1622-1634.

Das P, Murphy MP, Younkin LH, Younkin SG, Golde TE. 2001. Reduced effectiveness of $A \beta 1-42$ immunization in APP transgenic mice with significant amyloid deposition. Neurobiol Aging 22: 721-727.

Davidsson P, Puchades M, Blennow K. 1999. Identification of synaptic vesicle, pre- and postsynaptic proteins in human cerebrospinal fluid using liquid-phase isoelectric focusing. Electrophoresis 20: 431-437.

Dubois B, Feldman HH, Jacova C, Dekosky ST, BarbergerGateau P, Cummings J, et al. 2007. Research criteria for the diagnosis of Alzheimer's disease: Revising the NINCDS-ADRDA criteria. Lancet Neurol 6: 734-746.

Engelborghs S, De Vreese K, Van de Casteele T, Vanderstichele H, Van Everbroeck B, Cras P, Martin JJ, Vanmechelen E, De Deyn PP. 2008. Diagnostic performance of a CSF-biomarker panel in autopsy-confirmed dementia. Neurobiol Aging 29: 1143-1159.

Fagan AM, Mintun MA, Mach RH, Lee SY, Dence CS, Shah AR, LaRossa GN, Spinner ML, Klunk WE, Mathis CA et al. 2006. Inverse relation between in vivo amyloid imaging load and cerebrospinal fluid $A \beta 42$ in humans. Ann Neurol 59: 512-519.

Fagan AM, Roe CM, Xiong C, Mintun MA, Morris JC, Holtzman DM. 2007. Cerebrospinal fluid tau/ $\beta$-amyloid(42) ratio as a prediction of cognitive decline in nondemented older adults. Arch Neurol 64: 343-349.

Fagan AM, Head D, Shah AR, Marcus D, Mintun M, Morris JC, Holtzman DM. 2009a. Decreased cerebrospinal fluid $A \beta(42)$ correlates with brain atrophy in cognitively normal elderly. Ann Neurol 65: 176-183.

Fagan AM, Mintun MA, Shah AR, Aldea P, Roe CM, Mach RH, et al. 2009b. Cerebrospinal fluid tau and $\operatorname{ptau}_{181}$ increase with cortical amyloid deposition in cognitively normal individuals: Implications for future clinical trials of Alzheimer's disease. EMBO Mol Med 1: 371-380.

Fagan AM, Shaw LM, Xiong C, Vanderstichele H, Mintun MA, Trojanowski JQ, Coart E, Morris JC, Holtzman DM. 2011. Comparison of analytical platforms for cerebrospinal fluid measures of $\{\beta\}$-Amyloid $1-42$, total tau, and P-tau 181 for identifying Alzheimer disease amyloid plaque pathology. Arch Neurol 68: 1137-1144.

Finehout EJ, Franck Z, Choe LH, Relkin N, Lee KH. 2007. Cerebrospinal fluid proteomic biomarkers for Alzheimer's disease. Ann Neurol 61: 120-129.

Fjell AM, Walhovd KB, Fennema-Notestine C, McEvoy LK, Hagler DJ, Holland D, Blennow K, Brewer JB, Dale AM, the Alzheimer's Disease Neuorimaging Initiative. 2010. Brain atrophy in healthy aging is related to CSF levels of Aß1-42. Cereb Cortex 20: 2069-2079.

Fleisher AS, Raman R, Siemers ER, Becerra L, Clark CM, Dean RA, et al. 2008. Phase 2 safety trial targeting amyloid $\beta$ production with a $\gamma$-secretase inhibitor in Alzheimer disease. Arch Neurol 65: 1031-1038.

Forman MS, Farmer J, Johnson JK, Clark CM, Arnold SE, Coslett HB, Chatterjee A, Hurtig HI, Karlawish JH, Rosen
HJ, et al. 2006. Frontotemporal dementia: Clinicopathological correlations. Ann Neurol 59: 952-962.

Forsberg A, Engler H, Almkvist O, Blomquist G, Hagman G, Wall A, Ringheim A, Lángström B, Nordberg A. 2008. PET imaging of amyloid deposition in patients with mild cognitive impairment. Neurobiol Aging 29: 14561465.

Friede RL, Samorajski T. 1970. Axon caliber related to neurofilaments and microtubules in sciatic nerve fibers of rats and mice. Anat Rec 167: 379-387.

Frisoni GB, Prestia A, Zanetti O, Galluzzi S, Romano M, Cotelli M, Gennarelli M, Binetti G, Bocchio L, Paghera B, et al. 2009. Markers of Alzheimer's disease in a population attending a memory clinic. Alzheimer's Dement 5: 307-317.

Fukumoto H, Cheung BS, Hyman BT, Irizarry MC. 2002. $\beta$-Secretase protein and activity are increased in the neocortex in Alzheimer disease. Arch Neurol 59: 1381-1389.

Fukumoto H, Tokuda T, Kasai T, Ishigami N, Hidaka H, Kondo M, Allsop D, Nakagawa M. 2010. High-molecular-weight $\{\beta\}$-amyloid oligomers are elevated in cerebrospinal fluid of Alzheimer patients. FASEB $J$ 24: $2716-2726$.

Galasko D, Chang L, Motter R, Clark CM, Kaye J, Knopman D, Thomas R, Kholodenko D, Schenk D, Lieberburg I, et al. 1998. High cerebrospinal fluid tau and low amyloid $\beta 42$ levels in the clinical diagnosis of Alzheimer disease and relation to apolipoprotein E genotype. Arch Neurol 55: 937-945.

Ganguli M, Rodriguez E, Mulsant B, Richards S, Pandav R, Bilt JV, Dodge HH, Stoehr GP, Saxton J, Morycz RK, et al. 2004. Detection and management of cognitive impairment in primary care: The Steel Valley Seniors Survey. $J$ Am Geriatr Soc 52: 1668-16675.

Garcia-Alloza M, Subramanian M, Thyssen D, Borrelli LA, Fauq A, Das P, Golde TE, Hyman BT, Bacskai BJ. 2009. Existing plaques and neuritic abnormalities in APP:PS1 mice are not affected by administration of the $\gamma$-secretase inhibitor LY-411575. Mol Neurodegener 4: 19.

Georganopoulou DG, Chang L, Nam JM, Thaxton CS, Mufson EJ, Klein WL, Mirkin CA. 2005. Nanoparticle-based detection in cerebral spinal fluid of a soluble pathogenic biomarker for Alzheimer's disease. Proc Natl Acad Sci 102: $2273-2276$.

Gilman S, Koller M, Black RS, Jenkins L, Griffith SG, Fox NC, Eisner L, Kirby L, Rovira MB, Forette F, et al. 2005. Clinical effects of $A \beta$ immunization (AN1792) in patients with $\mathrm{AD}$ in an interrupted trial. Neurology 64: 1553-1562.

Glenner GG, Wong CW. 1984. Alzheimer's disease: Initial report of the purification and characterization of a novel cerebrovascular amyloid protein. Biochem Biophys Res Commun 120: 885-890.

Gotz J, Chen F, van Dorpe J, Nitsch RM. 2001. Formation of neurofibrillary tangles in P301l tau transgenic mice induced by A 42 fibrils. Science 293: 1491-1495.

Graff-Radford NR, Crook JE, Lucas J, Boeve BF, Knopman DS, Ivnik RJ, Smith GE, Younkin LH, Petersen RC, Younkin SG. 2007. Association of low plasma $A \beta 42 / A \beta 40$ ratios with increased imminent risk for mild cognitive impairment and Alzheimer disease. Arch Neurol 64: $354-362$. 
K. Blennow et al.

Grimmer T, Riemenschneider M, Förstl H, Henriksen G, Klunk WE, Mathis CA, Shiga T, Wester HJ, Kurz A, Drzezga A. 2009. $\beta$ Amyloid in Alzheimer's disease: Increased deposition in brain is reflected in reduced concentration in cerebrospinal fluid. Biol Psychiat 65: 927-934.

Grundke-Iqbal I, Iqbal K, Tung YC, Quinlan M, Wisniewski HM, Binder LI. 1986. Abnormal phosphorylation of the microtubule-associated protein tau (tau) in Alzheimer cytoskeletal pathology. Proc Natl Acad Sci 83: 4913-4917.

Gustafson DR, Skoog I, Rosengren L, Zetterberg H, Blennow K. 2007. Cerebrospinal fluid $\beta$-amyloid 1-42 concentration may predict cognitive decline in older women. $J$ Neurol Neurosurg Psychiat 78: 461-464.

Hampel H, Buerger K, Zinkowski R, Teipel SJ, Goernitz A, Andreasen N, Sjoegren M, DeBernardis J, Kerkman D, Ishiguro K, et al. 2004. Measurement of phosphorylated tau epitopes in the differential diagnosis of Alzheimer disease: A comparative cerebrospinal fluid study. Arch Gen Psychiat 61: 95-102.

Hampel H, Ewers M, Bürger K, Annas P, Mörtberg A, Bogstedt A, Frölich L, Schröder J, Schönknecht P, Riepe MW, et al. 2009. Lithium trial in Alzheimer's disease: A randomized, single-blind, placebo-controlled, multicenter 10-week study. J Clin Psychiat 70: 922-931.

Hansson O, Zetterberg H, Buchhave P, Londos E, Blennow K, Minthon L. 2006. Association between CSF biomarkers and incipient Alzheimer's disease in patients with mild cognitive impairment: A follow-up study. Lancet Neurol 5: 228-234.

Hansson O, Zetterberg H, Buchhave P, Andreasson U, Londos E, Minthon L, Blennow K. 2007a. Prediction of Alzheimer's disease using the CSF $A \beta 42 / A \beta 40$ ratio in patients with mild cognitive impairment. Dement Geriatr Cogn Disord 23: 316-320.

Hansson O, Buchhave P, Zetterberg H, Blennow K, Minthon L, Warkentin S. 2007b. Combined rCBF and CSF biomarkers predict progression from mild cognitive impairment to Alzheimer's disease. Neurobiol Aging 30: $165-173$.

Hardy J, Selkoe DJ. 2002. The amyloid hypothesis of Alzheimer's disease: Progress and problems on the road to therapeutics. Science 297: 353-356.

Hesse C, Rosengren L, Andreasen N, Davidsson P, Vanderstichele H, Vanmechelen E, Blennow K. 2001. Transient increase in total tau but not phospho-tau in human cerebrospinal fluid after acute stroke. Neurosci Lett 297: 187-190.

Holsinger RM, McLean CA, Collins SJ, Masters CL, Evin G. 2004. Increased $\beta$-Secretase activity in cerebrospinal fluid of Alzheimer's disease subjects. Ann Neurol 55: 898-899.

Hu WT, Chen-Plotkin A, Arnold SE, Grossman M, Clark CM, Shaw LM, Pickering E, Kuhn M, Chen Y, McCluskey L, et al. 2010. Novel CSF biomarkers for Alzheimer's disease and mild cognitive impairment. Acta Neuropathol 119: 669-678.

Hye A, Lynham S, Thambisetty M, Causevic M, Campbell J, Byers HL, Hooper C, Rijsdijk F, Tabrizi SJ, Banner S, et al. 2006. Proteome-based plasma biomarkers for Alzheimer's disease. Brain 129: 3042-3050.

Irizarry MC. Biomarkers of Alzheimer disease in plasma. 2004. NeuroRx 1: 226-234.
Jarrett JT, Berger EP, Lansbury PT Jr. 1993. The carboxy terminus of the $\beta$ amyloid protein is critical for the seeding of amyloid formation: Implications for the pathogenesis of Alzheimer's disease. Biochemistry 32: 4693-4697.

Jellinger KA. 1996. Diagnostic accuracy of Alzheimer's disease: A clinicopathological study. Acta Neuropathol (Berl) 91: 219-220.

Kadir A, Andreasen N, Almkvist O, Wall A, Forsberg A, Engler H, Hagman G, Larksater M, Winblad B, Zetterberg H, et al. 2008. Effect of phenserine treatment on brain functional activity and amyloid in Alzheimer's disease. Ann Neurol 63: 621-631.

Kang J, Lemaire HG, Unterbeck A, Salbaum JM, Masters CL, Grzeschik KH, Multhaup G, Beyreuther K, Müller-Hill B. 1987. The precursor of Alzheimer's disease amyloid A4 protein resembles a cell-surface receptor. Nature 325: 733-736.

Kauwe JS, Cruchaga C, Mayo K, Fenoglio C, Bertelsen S, Nowotny P, Galimberti D, Scarpini E, Morris JC, Fagan AM, et al. 2008. Variation in MAPT is associated with cerebrospinal fluid tau levels in the presence of amyloid- $\beta$ deposition. Proc Natl Acad Sci 105: 8050-8054.

Kauwe JS, Wang J, Mayo K, Morris JC, Fagan AM, Holtzman DM, Goate AM. 2009. Alzheimer's disease risk variants show association with cerebrospinal fluid amyloid $\beta$. Neurogenetics 10: 13-17.

Klyubin I, Betts V, Welzel AT, Blennow K, Zetterberg H, Wallin A, Lemere CA, Cullen WK, Peng Y, Wisniewski T, et al. 2008. Amyloid $\beta$ protein dimer-containing human CSF disrupts synaptic plasticity: Prevention by systemic passive immunization. J Neurosci 28: 4231-4237.

Knopman DS, DeKosky ST, Cummings JL, Chui H, CoreyBloom J, Relkin N, Small GW, Miller B, Stevens JC. 2001. Practice parameter: Diagnosis of dementia (an evidence-based review). Report of the Quality Standards Subcommittee of the American Academy of Neurology. Neurology 56: 1143-1153.

Kohnken R, Buerger K, Zinkowski R, Miller C, Kerkman D, DeBernardis J, Shen J, Möller HJ, Davies P, Hampel H. 2000. Detection of tau phosphorylated at threonine 231 in cerebrospinal fluid of Alzheimer's disease patients. Neurosci Lett 287: 187-190.

Koopman K, Le Bastard N, Martin JJ, Nagels G, De Deyn PP, Engelborghs S. 2009. Improved discrimination of autopsy-confirmed Alzheimer's disease (AD) from nonAD dementias using CSF P-tau(181P). Neurochem Int 55: $214-218$.

Kotzbauer PT, Trojanowsk JQ, Lee VM. 2001. Lewy body pathology in Alzheimer's disease. J Mol Neurosci 17: 225-232.

Kuo YM, Emmerling MR, Lampert HC, Hempelman SR, Kokjohn TA, Woods AS, Cotter RJ, Roher AE. 1999. High levels of circulating $A \beta 42$ are sequestered by plasma proteins in Alzheimer's disease. Biochem Biophys Res Commun 257: 787-791.

Lannfelt L, Blennow K, Zetterberg H, Batsman S, Ames D, Harrison J, Masters CL, Targum S, Bush AL, Murdoch R, et al. 2008. Safety, efficacy, and biomarker findings of PBT2 in targeting $A \beta$ as a modifying therapy for Alzheimer's disease: A phase IIa, double-blind, randomised, placebo-controlled trial. Lancet Neurol 7: 779-786. 
Lanz TA, Hosley JD, Adams WJ, Merchant KM. 2004. Studies of $A \beta$ pharmacodynamics in the brain, cerebrospinal fluid, and plasma in young (plaque-free) Tg2576 mice using the $\gamma$-secretase inhibitor N2-[(2S)-2-(3,5-difluorophenyl)-2-hydroxyethanoyl]-N1-[(7S)-5-methyl-6-oxo6,7-dihydro-5H-dibenzo[b,d] azepin-7-yl]-L-alaninamide (LY-411575). J Pharmacol Exp Ther 309: 49-55.

Laterza OF, Modur VR, Crimmins DL, Olander JV, Landt Y, Lee JM, Ladenson JH. 2006. Identification of novel brain biomarkers. Clin Chem 52: 1713-1721.

Lee JM, Blennow K, Andreasen N, Laterza O, Modur V, Olander J, Gao F, Ohlendorf M, Ladenson JH. 2008. The brain injury biomarker VLP-1 is increased in the cerebrospinal fluid of Alzheimer disease patients. Clin Chem 54: 1617-1623.

Lewczuk P, Esselmann H, Meyer M, Wollscheid V, Neumann M, Otto M, Maler JM, Rüther E, Kornhuber J, Wiltfang J. 2003. The amyloid- $\beta$ (A $\beta$ ) peptide pattern in cerebrospinal fluid in Alzheimer's disease: Evidence of a novel carboxyterminally elongated $A \beta$ peptide. Rapid Commun Mass Spectrom 17: 1291-1296.

Lewczuk P, Kornhuber J, Vanderstichele H, Vanmechelen E, Esselmann H, Bibl M, Wolf S, Otto M, Reulbach U, Kölsch H, et al. 2008. Multiplexed quantification of dementia biomarkers in the CSF of patients with early dementias and MCI: A multicenter study. Neurobiol Aging 29: 812-818.

Lewczuk P, Kamrowski-Kruck H, Peters O, Heuser I, Jessen F, Popp J, Bürger K, Hampel H, Frölich L, Wolf S, et al. 2010. Soluble amyloid precursor proteins in the cerebrospinal fluid as novel potential biomarkers of Alzheimer's disease: A multicenter study. Mol Psychiat 15: 138-145.

Lewis J, Dickson DW, Lin WL, Chisholm L, Corral A, Jones G, Yen SH, Sahara N, Skipper L, Yager D, et al. 2001. Enhanced neurofibrillary degeneration in transgenic mice expressing mutant tau and APP. Science 293: 1487-1491.

Levites Y, Das P, Price RW, Rochette MJ, Kostura LA, McGowan EM, Murphy MP, Golde TE. 2006. Anti-A $\beta_{42^{-}}$and anti- $\mathrm{A} \beta_{40}$-specific mAbs attenuate amyloid deposition in an Alzheimer disease mouse model. J Clin Invest 116: 193-201.

Li G, Sokal I, Quinn JF, Leverenz JB, Brodey M, Schellenberg GD, et al. 2007. CSF tau/Aß42 ratio for increased risk of mild cognitive impairment: A follow-up study. Neurology 69: 631-639.

Maddalena A, Papassotiropoulos A, Muller-Tillmanns B, Jung HH, Hegi T, Nitsch RM, Hock C. 2003. Biochemical diagnosis of Alzheimer disease by measuring the cerebrospinal fluid ratio of phosphorylated tau protein to $\beta$ amyloid peptide $_{42}$. Arch Neurol 60: 1202-1206.

Masters CL, Simms G, Weinman NA, Multhaup G, McDonald BL, Beyreuther K. 1985. Amyloid plaque core protein in Alzheimer disease and Down syndrome. Proc Natl Acad Sci 82: 4245-4249.

Mattsson N, Zetterberg H, Hansson O, Andreasen N, Parnetti L, Jonsson M, Herukka SK, van der Flier WM, Blankenstein MA, Ewers M, et al. 2009. CSF biomarkers and incipient Alzheimer disease in patients with mild cognitive impairment. JAMA 302: 385-393.

Mattsson N, Andreasson U, Persson S, Arai H, Batish SD, Bernardini S, Bocchio-Chiavetto L, Blankenstein MA,
Carrillo MC, Chalbot S. 2011. The Alzheimer's Association external quality control program for cerebrospinal fluid biomarkers. Alzheimers Dement 7: 386-395.

Mawuenyega KG, Sigurdson W, Ovod V, Munsell L, Kasten T, Morris JC, Yarasheski KE, Bateman RJ. 2010. Decreased clearance of CNS $\beta$-amyloid in Alzheimer's disease. Science 330, 1774.

Mayeux R, Honig LS, Tang MX, Manly J, Stern Y, Schupf N, Mehta PD. 2003. Plasma $A \beta 40$ and $A \beta 42$ and Alzheimer's disease: Relation to age, mortality, and risk. Neurology 61: 1185-1190.

McKhann G, Drachman D, Folstein M, Katzman R, Price D, Stadlan EM. 1984. Clinical diagnosis of Alzheimer's disease: Report of the NINCDS-ADRDAWork Group under the auspices of Department of Health and Human Services Task Force on Alzheimer's Disease. Neurology 34: 939-944.

McKhann GM, Knopman DS, Chertkow H, Hyman BT, Jack CR Jr, Kawas CH, Klunk WE, Koroshetz WJ, Manly JJ, Mayeux R, et al. 2011. The diagnosis of dementia due to Alzheimer's disease: Recommendations from the National Institute on Aging-Alzheimer's Association workgroups on diagnostic guidelines for Alzheimer's disease. Alzheimer's Dement 7, 263-269.

Mehta PD, Pirttila T, Mehta SP, Sersen EA, Aisen PS, Wisniewski HM. 2000. Plasma and cerebrospinal fluid levels of amyloid $\beta$ proteins $1-40$ and $1-42$ in Alzheimer disease. Arch Neurol 57: 100-105.

Montine TJ, Quinn J, Kaye J, Morrow JD. 2007. F(2)-isoprostanes as biomarkers of late-onset Alzheimer's disease. J Mol Neurosci 33: 114-119.

Moonis M, Swearer JM, Dayaw MP, St. George-Hyslop P, Rogaeva E, Kawarai T, Pollen DA. 2005. Familial Alzheimer disease: Decreases in CSF $\alpha \beta_{42}$ levels precede cognitive decline. Neurology 65: 323-325.

Nyberg S, Jonhagen ME, Cselenyi Z, Halldin C, Julin P, Olsson H, Freund-Levi Y, Andersson J, Varnas K, Svensson S, et al. 2009. Detection of amyloid in Alzheimer's disease with positron emission tomography using [11C]AZD2184. Eur J Nucl Med Mol Imaging 36: 18591863.

Okamura N, Arai H, Maruyama M, Higuchi M, Matsui T, Tanji H, Seki T, Hirai $H$, Chiba $H$, Itoh $M$, et al. 2002. Combined analysis of CSF tau levels and [(123)I]Iodoamphetamine SPECT in mild cognitive impairment: Implications for a novel predictor of Alzheimer's disease. Am J Psychiat 159: 474-476.

Olsson A, Hoglund K, Sjogren M, Andreasen N, Minthon L, Lannfelt L, Buerger K, Moller HJ, Hampel H, Davidsson $P$, et al. 2003. Measurement of $\alpha$ - and $\beta$-secretase cleaved amyloid precursor protein in cerebrospinal fluid from Alzheimer patients. Exp Neurol 183: 74-80.

Olsson A, Vanderstichele H, Andreasen N, De Meyer G, Wallin A, Holmberg B, Rosengren L, Vanmechelen E, Blennow K. 2005. Simultaneous measurement of $\beta$-amy$\operatorname{loid}_{(1-42)}$, total tau, and phosphorylated tau $\left(\mathrm{Thr}^{181}\right)$ in cerebrospinal fluid by the xMAP technology. Clin Chem 51: $336-345$

Orgogozo JM, Gilman S, Dartigues JF, Laurent B, Puel M, Kirby LC, Jouanny P, Dubois B, Eisner L, Flitman S, et al. 2003. Subacute meningoencephalitis in a subset of 
K. Blennow et al.

patients with $\mathrm{AD}$ after $\mathrm{A} \beta 42$ immunization. Neurology 61: $46-54$.

Ost M, Nylén K, Csajbok L, Ohrfelt AO, Tullberg M, Wikkelsö C, Nellgárd P, Rosengren L, Blennow K, Nellgárd B. 2006. Initial CSF total tau correlates with 1-year outcome in patients with traumatic brain injury. Neurology 67: $1600-1604$.

Otto M, Wiltfang J, Tumani H, Zerr I, Lantsch M, Kornhuber J, Weber T, Kretzschmar HA, Poser S. 1997. Elevated levels of tau-protein in cerebrospinal fluid of patients with Creutzfeldt-Jakob disease. Neurosci Lett 225: $210-212$.

Pomara N, Willoughby LM, Sidtis JJ, Mehta PD. 2005. Selective reductions in plasma $A \beta 1-42$ in healthy elderly subjects during longitudinal follow-up: A preliminary report. Am J Geriatr Psychiat 13: 914-917.

Portelius E, Westman-Brinkmalm A, Zetterberg H, Blennow K. 2006a. Determination of $\beta$-amyloid peptide signatures in cerebrospinal fluid using immunoprecipitation-mass spectrometry. J Proteome Res 5: 1010-1016.

Portelius E, Zetterberg H, Andreasson U, Brinkmalm G, Andreasen N, Wallin A, et al. 2006b. An Alzheimer's disease-specific $\beta$-amyloid fragment signature in cerebrospinal fluid. Neurosci Lett 409: 215-219.

Portelius E, Hansson SF, Tran AJ, Zetterberg H, Grognet P, Vanmechelen E, Höglund K, Brinkmalm G, WestmanBrickmalm A, Nordhoff E, et al. 2008. Characterization of tau in cerebrospinal fluid using mass spectrometry. $J$ Proteome Res 7: 2114-2120.

Portelius E, Price E, Brinkmalm G, Stiteler M, Olsson M, Persson R, et al. 2009. A novel pathway for amyloid precursor protein processing. Neurobiol Aging 32: 1090-1098.

Portelius E, Andreasson U, Ringman JM, Buerger K, Daborg J, Buchhave P, et al. 2010. Distinct cerebrospinal fluid amyloid $\beta$ peptide signatures in sporadic and PSEN1 A431E-associated familial Alzheimer's disease. $\mathrm{Mol} \mathrm{Neu-}$ rodegener 5: 2 .

Price JL, Morris JC. 1999. Tangles and plaques in nondemented aging and "preclinical" Alzheimer's disease. Ann Neurol 45: 358-368.

Raschetti R, Albanese E, Vanacore N, Maggini M. 2007. Cholinesterase inhibitors in mild cognitive impairment A systematic review of randomised trials. PLoS Med 4: e338.

Ray S, Britschgi M, Herbert C, Takeda-Uchimura Y, Boxer A, Blennow K, Friedman LF, Galasko DR, Jutel M, Karydas A, et al. 2007. Classification and prediction of clinical Alzheimer's diagnosis based on plasma signaling proteins. Nat Med 13: 1359-1362.

Riemenschneider M, Lautenschlager N, Wagenpfeil S, Diehl J, Drzezga A, Kurz A. 2002. Cerebrospinal fluid tau and $\beta$-amyloid 42 proteins identify Alzheimer disease in subjects with mild cognitive impairment. Arch Neurol 59: 1729-1734.

Ringman JM, Younkin SG, Pratico D, Seltzer W, Cole GM, Geschwind DH, et al. 2008. Biochemical markers in persons with preclinical familial Alzheimer disease. Neurology 71: 85-92.

Salloway S, Sperling R, Gilman S, Fox NC, Blennow K, Raskind M, Sabbagh M, Honig LS, Doody R, van Dyck CH et al. 2009. A phase 2 trial of bapineuzumab in mild to moderate Alzheimer's disease. Neurology 73: 2061-2070.
Samgard K, Zetterberg H, Blennow K, Hansson O, Minthon L, Londos E. 2009. Cerebrospinal fluid total tau as a marker of Alzheimer's disease intensity. Int J Geriatr Psychiat 25: 403-410.

Sankaranarayanan S, Holahan MA, Colussi D, Crouthamel MC, Devanarayan V, Ellis J, Espeseth A, Gates AT, Graham SL, Gregro AR, et al. 2009. First demonstration of cerebrospinal fluid and plasma A $\beta$ lowering with oral administration of a $\beta$-site amyloid precursor proteincleaving enzyme 1 inhibitor in nonhuman primates. $J$ Pharmacol Exp Ther 328: 131-140.

Santos AN, Torkler S, Nowak D, Schlittig C, Goerdes M, Lauber T, Trischmann L, Schaupp M, Penz M, Tiller FW, et al. 2007. Detection of amyloid- $\beta$ oligomers in human cerebrospinal fluid by flow cytometry and fluorescence resonance energy transfer. J Alzheimer's Dis 11: 117-125.

Schneider JA, Arvanitakis Z, Leurgans SE, Bennett DA. 2009. The neuropathology of probable Alzheimer's disease and mild cognitive impairment. Ann Neurol 66: 200-208.

Schoonenboom NS, Mulder C, Van Kamp GJ, Mehta SP, Scheltens P, Blankenstein MA, Mehta PD. 2005. Amyloid $\beta 38,40$, and 42 species in cerebrospinal fluid: More of the same? Ann Neurol 58: 139-142.

Schoonenboom NS, van der Flier WM, Blankenstein MA, Bouwman FH, Van Kamp GJ, Barkhof F, Scheltens P. 2008. CSF and MRI markers independently contribute to the diagnosis of Alzheimer's disease. Neurobiol Aging 29: 669-675.

Seubert P, Vigo-Pelfrey C, Esch F, Lee M, Dovey H, Davis D, Sinha S, Schlossmacher M, Whaley J, Swindlehurst C, et al. 1992. Isolation and quantification of soluble Alzheimer's $\beta$-peptide from biological fluids. Nature 359: 325-327.

Shaw LM, Vanderstichele H, Knapik-Czajka M, Clark CM, Aisen PS, Petersen RC, Blennow K, Soares H, Simon A, Lewczuk P, et al. 2009. Cerebrospinal fluid biomarker signature in Alzheimer's disease neuroimaging initiative subjects. Ann Neurol 65: 403-413.

Siemers ER. 2009. How can we recognize "disease modification" effects? J Nutr Health Aging 13: 341-343.

Sjogren M, Rosengren L, Minthon L, Davidsson P, Blennow K, Wallin A. 2000. Cytoskeleton proteins in CSF distinguish frontotemporal dementia from AD. Neurology 54: 1960-1964.

Sjogren M, Blomberg M, Jonsson M, Wahlund LO, Edman A, Lind K, Rosengren L, Blennow K, Wallin A. 2001a. Neurofilament protein in cerebrospinal fluid: A marker of white matter changes. J Neurosci Res 66: 510-516.

Sjogren M, Davidsson P, Gottfries J, Vanderstichele H, Edman A, Vanmechelen E, Wallin A, Blennow K. 2001b. The cerebrospinal fluid levels of tau, growth-associated protein- 43 and soluble amyloid precursor protein correlate in Alzheimer's disease, reflecting a common pathophysiological process. Dement Geriatr Cogn Disord 12: $257-264$.

Skoog I, Davidsson P, Aevarsson O, Vanderstichele H, Vanmechelen E, Blennow K. 2003. Cerebrospinal fluid $\beta$-amyloid 42 is reduced before the onset of sporadic dementia: A population-based study in 85 -year-olds. Dement Geriatr Cogn Disord 15: 169-176. 
Snider BJ, Fagan AM, Roe C, Shah AR, Grant EA, Xiong C, Morris JC, Holtzman DM. 2009. Cerebrospinal fluid biomarkers and rate of cognitive decline in very mild dementia of the Alzheimer type. Arch Neurol 66: 638-645.

Snowdon DA. 1997. Aging and Alzheimer's disease: Lessons from the Nun Study. Gerontologist 37: 150-156.

Sperling RA, Aisen PS, Beckett LA, Bennett DA, Craft S, Fagan AM, Iwatsubo T, Jack CR Jr, Kaye J, Montine TJ, et al. 2011. Toward defining the preclinical stages of Alzheimer's disease: Recommendations from the National Institute on Aging-Alzheimer's Association workgroups on diagnostic guidelines for Alzheimer's disease. Alzheimer's Dement 7, 280-292.

Stomrud E, Hansson O, Blennow K, Minthon L, Londos E. 2007. Cerebrospinal fluid biomarkers predict decline in subjective cognitive function over 3 years in healthy elderly. Dement Geriatr Cogn Disord 24: 118-124.

Storandt M, Grant EA, Miller JP, Morris JC. 2006. Longitudinal course and neuropathologic outcomes in original vs revised MCI and in pre-MCI. Neurology 67: 467-473.

Strozyk D, Blennow K, White LR, Launer LJ. 2003. CSF A $\beta$ 42 levels correlate with amyloid-neuropathology in a population-based autopsy study. Neurology 60: 652-656.

Sunderland T, Linker G, Mirza N, Putnam KT, Friedman DL, Kimmel LH, Bergeson J, Manetti GJ, Zimmermann M, Tang B, et al. 2003. Decreased $\beta$-amyloid ${ }_{1-42}$ and increased tau levels in cerebrospinal fluid of patients with Alzheimer disease. JAMA 289: 2094-2103.

Tapiola T, Alafuzoff I, Herukka SK, Parkkinen L, Hartikainen P, Soininen H, Pirttilä T. 2009. Cerebrospinal fluid $\beta$-amyloid 42 and tau proteins as biomarkers of Alzheimer-type pathologic changes in the brain. Arch Neurol 66: 382-389.

Tarawneh R, D'Angelo G, Macy E, Xiong C, Carter D, Cairns NJ, Fagan AM, Head D, Mintun MA, Ladenson JH, Lee JM, Morris JC, Holtzman DM, et al. 2011. Visin-like protein-1: Diagnostic and prognostic biomarker in Alzheimer disease. Ann Neurol 70: 274-285.

Terry RD, Masliah E, Salmon DP, Butters N, DeTeresa R, Hill R, Hansen LA, Katzman R. 1991. Physical basis of cognitive alterations in Alzheimer's disease: Synapse loss is the major correlate of cognitive impairment. Ann Neurol 30: $572-580$.

Tibbling G, Link H, Ohman S. 1977. Principles of albumin and IgG analyses in neurological disorders. I. Establishment of reference values. Scand J Clin Lab Invest 37: 385-390.

Tolboom N, van der Flier WM, Yaqub M, Boellaard R, Verwey NA, Blankenstein MA, Windhorst AD, Scheltens P, Lammertsma AA, van Berckel BN. 2009. Relationship of cerebrospinal fluid markers to ${ }^{11} \mathrm{C}-\mathrm{PiB}$ and ${ }^{18} \mathrm{~F}-$ FDDNP binding. J Nucl Med 50: 1464-1470.

Vanmechelen E, Vanderstichele H, Davidsson P, Van Kerschaver E, Van Der Perre B, Sjögren M, Andreasen N, Blennow K. 2000. Quantification of tau phosphorylated at threonine 181 in human cerebrospinal fluid: A sandwich ELISA with a synthetic phosphopeptide for standardization. Neurosci Lett 285: 49-52.

van Oijen M, Hofman A, Soares HD, Koudstaal PJ, Breteler MM. 2006. Plasma $A \beta(1-40)$ and $A \beta(1-42)$ and the risk of dementia: A prospective case-cohort study. Lancet Neurol 5: 655-660.
Vellas B. 2009. Editorial: Use of biomarkers in Alzheimer's trials. J Nutr Health Aging 13: 331.

Vemuri P, Wiste HJ, Weigand SD, Shaw LM, Trojanowski JQ, Weiner MW, Knopman DS, Petersen RC, Jack CR Jr, Alzheimer's Disease Neuroimaging Initiative. 2009. $\mathrm{MRI}$ and CSF biomarkers in normal, $\mathrm{MCI}$, and $\mathrm{AD}$ subjects: Diagnostic discrimination and cognitive correlations. Neurology 73: 287-293.

Visser PJ, Scheltens P, Verhey FR. 2005. Do MCI criteria in drug trials accurately identify subjects with predementia Alzheimer's disease? J Neurol Neurosurg Psychiat 76: $1348-1354$.

Visser PJ, Verhey F, Knol DL, Scheltens P, Wahlund LO, Freund-Levi Y, Tsolaki M, Minthon L, Wallin AK, Hampel H, et al. 2009. Prevalence and prognostic value of CSF markers of Alzheimer's disease pathology in patients with subjective cognitive impairment or mild cognitive impairment in the DESCRIPA study: A prospective cohort study. Lancet Neurol 8: 619-627.

Wallin AK, Hansson O, Blennow K, Londos E, Minthon L. 2009. Can CSF biomarkers or pre-treatment progression rate predict response to cholinesterase inhibitor treatment in Alzheimer's disease? Int J Geriatr Psychiat 24: 638-647.

Walsh DM, Selkoe DJ. 2007. A $\beta$ oligomers-A decade of discovery. J Neurochem 101: 1172-1184.

World Health Organization. 1992. ICD-10: International statistical classification of diseases, 10th ed. WHO, Geneva.

Yang LB, Lindholm K, Yan R, Citron M, Xia W, Yang XL, Beach T, Sue L, Wong P, Price D, et al. 2003. Elevated $\beta$-secretase expression and enzymatic activity detected in sporadic Alzheimer disease. Nat Med 9: 3-4.

Zetterberg H, Wahlund LO, Blennow K. 2003. Cerebrospinal fluid markers for prediction of Alzheimer's disease. Neurosci Lett 352: 67-69.

Zetterberg H, Andreasen N, Blennow K. 2004. Increased cerebrospinal fluid levels of transforming growth factor- $\beta 1$ in Alzheimer's disease. Neurosci Lett 367: 194-196.

Zetterberg H, Hietala MA, Jonsson M, Andreasen N, Styrud E, Karlsson I, Edman A, Popa C, Rasulzada A, Wahlund LO, et al. 2006. Neurochemical aftermath of amateur boxing. Arch Neurol 63: 1277-1280.

Zetterberg H, Pedersen M, Lind K, Svensson M, Rolstad S, Eckerström C, Syversen S, Mattsson UB, Ysander C, Mattsson N, et al. 2007. Intra-individual stability of CSF biomarkers for Alzheimer's disease over two years. J Alzheimer's Dis 12: 255-260.

Zetterberg H, Andreasson U, Hansson O, Wu G, Sankaranarayanan S, Andersson ME, Buchhave P, Londos E, Umek RM, Minthon L, et al. 2008. Elevated cerebrospinal fluid BACE1 activity in incipient Alzheimer disease. Arch Neurol 65: 1102-1107.

Zhang Y, Londos E, Minthon L, Wattmo C, Liu H, Aspelin P, Wahlund LO. 2008. Usefulness of computed tomography linear measurements in diagnosing Alzheimer's disease. Acta Radiol 49: 91-97.

Zhong Z, Ewers M, Teipel S, Burger K, Wallin A, Blennow K, He P, McAllister C, Hampel H, Shen Y. 2007. Levels of $\beta$-secretase (BACE1) in cerebrospinal fluid as a predictor of risk in mild cognitive impairment. Arch Gen Psychiat 64: $718-726$. 


\section{$\&_{\mathrm{CSH}}^{\infty} \&$ Cold Spring Harbor

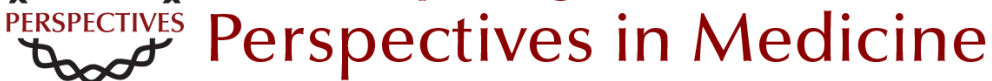

\section{Fluid Biomarkers in Alzheimer Disease}

Kaj Blennow, Henrik Zetterberg and Anne M. Fagan

Cold Spring Harb Perspect Med 2012; doi: 10.1101/cshperspect.a006221 originally published online April 17,2012

\section{Subject Collection The Biology of Alzheimer Disease}

Animal Models of Alzheimer Disease

Frank M. LaFerla and Kim N. Green

Neurovascular Dysfunction and Faulty Amyloid $\beta$

-Peptide Clearance in Alzheimer Disease Abhay P. Sagare, Robert D. Bell and Berislav V. Zlokovic

Treatment Strategies Targeting Amyloid $\beta$-Protein Dale Schenk, Guriqbal S. Basi and Menelas N. Pangalos

The Ubiquitin-Proteasome System and the Autophagic-Lysosomal System in Alzheimer Disease

Yasuo Ihara, Maho Morishima-Kawashima and Ralph Nixon

Neurotoxicity of Amyloid $\beta$-Protein: Synaptic and Network Dysfunction Lennart Mucke and Dennis J. Selkoe

Proteolytic Degradation of Amyloid $\beta$-Protein Takaomi Saido and Malcolm A. Leissring

Brain Imaging in Alzheimer Disease

Keith A. Johnson, Nick C. Fox, Reisa A. Sperling, et al.

Symptomatic and Nonamyloid/Tau Based Pharmacologic Treatment for Alzheimer Disease Paul S. Aisen, Jeffrey Cummings and Lon S. Schneider
Alzheimer Disease in 2020

David M. Holtzman, Eckhard Mandelkow and

Dennis J. Selkoe

The Genetics of Alzheimer Disease Rudolph E. Tanzi

Fluid Biomarkers in Alzheimer Disease

Kaj Blennow, Henrik Zetterberg and Anne M. Fagan

Epidemiology of Alzheimer Disease

Richard Mayeux and Yaakov Stern

Biochemistry and Cell Biology of Tau Protein in Neurofibrillary Degeneration

Eva-Maria Mandelkow and Eckhard Mandelkow

Biochemistry of Amyloid $\beta$-Protein and Amyloid Deposits in Alzheimer Disease

Colin L. Masters and Dennis J. Selkoe

The Neuropsychological Profile of Alzheimer

Disease

Sandra Weintraub, Alissa H. Wicklund and David P. Salmon

Apolipoprotein E and Apolipoprotein E Receptors: Normal Biology and Roles in Alzheimer Disease David M. Holtzman, Joachim Herz and Guojun Bu

For additional articles in this collection, see http://perspectivesinmedicine.cshlp.org/cgi/collection/ 